\title{
基于二维材料纳米孔的生物传感器：计算和模拟 研究进展
}

周万琦 ${ }^{1,2}$, 仇虎 ${ }^{1,2^{*}}$, 郭宇锋 ${ }^{1,2}$, 郭万林 $^{1,2}$

1. 南京航空航天大学, 机械结构力学及控制国家重点实验室, 南京 210016;

2. 南京航空航天大学, 纳智能材料器件教育部重点实验室, 南京 210016

*联系人, E-mail: qiuhu@nuaa.edu.cn

2020-08-21 收稿, 2020-10-16 修回, 2020-10-29 接受, 2020-11-06 网络版发表

国家自然科学基金(11772152，11972186，51535005)、江苏省自然科学基金(BK20180065)和江苏省“六大人才高峰”高层次人才项目(SWYY024)资助

摘要 近年来, 基于纳米孔的生物传感器被广泛用于DNA、RNA和蛋白质等生物分子的检测和分析. 以DNA测序 为例, 纳米孔测序摒弃了样本扩增和荧光标记等步骤, 与传统测序技术相比, 在成本、读取长度和效率等方面具有 明显优势. 过去 10 年间, 拥有优异力学、电学、光学等性质的石墨烯和其他二维材料受到了纳米孔传感器领域研 究人员的关注. 一方面, 这是因为它们极低的厚度有望提供远高于氮化硅、氧化硅等传统固态纳米孔材料的空间 分辨率; 另一方面, 除常用的离子电流测量外, 导电二维材料的应用还提供了膜内横向电流这一带宽更高的测量途 径. 在纳米孔传感器的研制过程中, 能实时“观测”纳米孔内原子、分子尺度相互作用规律的理论和计算模拟工具 发挥了重要作用, 包括预测分析原理、优化器件性能、解释实验现象等. 本文从计算和模拟角度出发, 综述了过 去 10 年间基于二维材料纳米孔生物传感器研究的关键历程, 分析了制约二维材料纳米孔传感器性能的关键因素, 讨论了该领域目前所面临的挑战和可能的解决方法, 最后展望了未来值得努力的方向.

关键词 纳米孔传感, DNA测序, 二维材料, 石墨烯, 理论计算

直径为 1 100 $\mathrm{nm}$ 的狭窄孔道被称为纳米孔(nanopore). 具有存储和运输功能的纳米孔在高效传感、海 水过滤、污水处理、药物投递和燃料电池等多个领域 展现出广阔的应用前景. 以纳米孔传感为例, 过去 20 年 来, 基于纳米孔的检测技术发展非常迅速, 可用于检测 各种离子、分子的特性，包括金属离子、小分子、 DNA、RNA、聚合物和蛋白质等 ${ }^{[1]}$. 举例来说，对 DNA这一生命系统中最重要分子的序列信息(即组成 DNA的4种核苷酸A、T、C 和G的排列顺序)的测定被 称为DNA测序. 低成本、短耗时的DNA测序方法在临 床应用上的普及将惠及癌症等疾病的风险评估、早期
诊断以及基于个体基因背景的个性化医疗等先进医疗 技术的发展. 作为第三代测序技术的代表, 纳米孔测序 (nanopore sequencing)摒弃传统测序技术中必须经过化 学标记或样品扩增等昂贵且耗时的样品准备等步骤, 是一种单分子层次的检测手段, 因此相较于传统测序 方法能大幅度降低时间和成本.

\section{1 纳米孔检测的原理和历史}

纳米孔检测的基本原理非常简单(图1): 用1个含有 纳米孔的薄膜隔断 2 个电解液腔, 接着分别在 2 个腔体 中插人电极并施加电压, 诱发稳定的跨越纳米孔的离 
图 1 (网络版彩色)基于纳米孔的生物传感器工作原理示意图. 外加 电场驱动溶液中的被分析物分子(如DNA、RNA)跨越纳米孔, 引起 离子电流阻塞. 每个离子电流阻塞信号的幅值 $\left(\delta_{\mathrm{I}}\right)$ 、持续时间 $\left(t_{\mathrm{d}}\right)$ 、 相邻阻塞的间隔 $\left(\delta_{t}\right)$ 等参数可用于解析分子的构型甚至身份等信息. 常用纳米孔分为蛋白孔和固态孔两大类, 其中固态孔包括氮化硅纳 米孔、氧化硅纳米孔和石墨烯、六方氮化嗍和二硫化钿等二维材料 纳米孔. 当采用具有导电性的二维材料(如石墨烯纳米带)构筑纳米孔 时, 还可通过测量膜内横向电流来检测被分析物

Figure 1 (Color online) Schematic of the nanopore system for detecting single molecule. As a transmembrane voltage bias is applied, analytes (such as DNA and RNA) in solution are driven through the nanopore, causing ionic current blockade. The dwell time $\left(t_{\mathrm{d}}\right)$, amplitude $\left(\delta_{\mathrm{I}}\right)$, and the time between successive events $\left(\delta_{\mathrm{t}}\right)$ of the ionic current blockade reflect information of molecular configuration and even its identity. The widely used nanopores can be classified into two groups: Protein nanopores and solid-state nanopores; the latter include silicon nitride nanopores, silica nanopores as well as two-dimensional (2D) material nanopores in graphene, $\mathrm{h}-\mathrm{BN}, \mathrm{MoS}_{2}$ and etc. When fabricating nanopores with conducting $2 \mathrm{D}$ materials (such as graphene nanoribbons), one can measure the transverse current of the nanoribbons, as well, to detect analytes

子电流(ionic current) ${ }^{[2]}$. DNA、RNA和蛋白质等被分析 物分子在外加电场的驱动下逐一通过纳米孔，流过纳 米孔的离子电流信号会受到孔内待测物的影响而发生 明显的变化, 即造成离子电流阻塞(ionic current blockade). 人们通过对离子电流阻塞信号的幅值 $\left(\delta_{\mathrm{I}}\right)$ 、持续 时间 $\left(t_{\mathrm{d}}\right)$ 、间隔时间 $\left(\delta_{\mathrm{t}}\right)$ 等特征的分析可解析出被分析 物的结构特征等信息. 当被分析物为DNA分子时, 理论 上来说对高分辨率离子电流信号的分析能够依次识别 序列中每个碱基的类型, 进而获得整个DNA序列, 即前 述的DNA测序.

膜材料作为纳米孔传感器的关键部件, 对其择优 选取和优化设计一直是整个领域的关注焦点. 从材料 类型上来看, 主要分为内嵌膜蛋白的生物细胞膜和人 工合成的固态膜(solid-state membrane)两种. 在细胞膜
中，嵌在其中的一些膜蛋白内部存在天然的纳米通道, 被称为生物纳米孔或蛋白纳米孔，其典型代表为 $\alpha$-溶 血素 $(\alpha$-hemolysin)和MspA蛋白等. 1996年，Kasianowicz 等人 ${ }^{[3]}$ 首次完成了单链DNA和RNA分子通过 $\alpha$-溶 血素蛋白孔的实验. 随后, 各种不同类型的蛋白纳米孔 都被提出用于单分子检测, 且性能表现各异. 例如, 大 量研究表明 $\mathrm{MspA}$ 蛋白纳米孔在检测分辨率、信噪比 等诸多方面都明显优于 $\alpha$-溶血素蛋白纳米孔 ${ }^{[4 \sim 6]}$; 此外, 研究人员基于aerolysin蛋白纳米孔能实时“观测”寡核 苷酸链被核酸外切酶逐步切除的过程 ${ }^{[7]}$. 除实验室研究 外, Oxford Nanopore Technologies公司发布了基于生物 蛋白纳米孔的商用DNA测序仪平台MinION, 初步实现 了生物孔测序技术的商业化 ${ }^{[8,9]}$.

尽管生物纳米孔广受关注, 但是其存在许多公认的 固有缺陷. 例如, 支撑生物孔的细胞膜稳定性不高, 生物 孔检测的敏感性受实验条件 ( $\mathrm{pH}$ 、温度、溶液浓度等) 影响较大, 以及难以整合成大规模的阵列 ${ }^{[10]}$. 生物孔的 这些缺陷驱使人们开始关注由人工合成的固态膜材料 加工而成的纳米孔一一固态纳米孔. 除了优于生物孔系 统的稳定性和耐久性以外, 基于固态膜材料的纳米孔还 具有尺寸和形状可定制、可制造高密度阵列、可与电 学和光学读取技术相结合等优点. 基于氮化硅、氧化硅 和氧化铝等固态膜材料, 通过离子束或聚焦电子束击穿 等方式加工为固态纳米孔. 早在2001年, Golovchenko课 题组 ${ }^{[11]}$ 首次进行了DNA通过氮化硅纳米孔的实验. 近 年来, 纳米科技的蓬勃发展, 尤其是石墨烯等新颖二维 材料的不断涌现, 为固态纳米孔检测领域注人了新的活 力. 二维材料的厚度(可低至单原子层)与DNA链上相邻 碱基间的距离 $(0.34 \mathrm{~nm})$ 相当. 因此, 相较于固态纳米孔 内容纳的多个碱基同时影响离子电流, 以二维材料作为 固态膜制成的纳米孔在同一时刻只能容纳单个DNA碱 基, 故具有潜在的分辨单碱基的能力. 该潜力将极大化 地降低离子电流分析难度, 有望大幅度提高纳米孔测序 的效率. 除此以外，与绝缘的氮化硅等传统固态膜材料 不同, 很多二维材料还具有导电性. 因此, 除了通过检测 穿过二维材料纳米孔的离子电流外, 还可通过测量膜内 部的横向电流(或隧道电流)来读取被分析物分子的结 构和序列信息(图1).2010年，3个独立课题组几乎同时 报道了DNA分子通过石墨烯纳米孔的实验 ${ }^{[12 \sim 14]}$. 随后, 二硫化锄 $\left(\mathrm{MoS}_{2}\right)^{[15 \sim 17]}$ 、六方氮化硼 $(\mathrm{h}-\mathrm{BN})^{[18,19]}$ 等二维 材料也纷纷被提出用于纳米孔传感. 以上工作都证明 DNA穿过二维材料纳米孔时可以引发开孔电流的变化, 
说明二维材料纳米孔具有被用于DNA分析检测，甚至 DNA测序的潜力.

尽管取得了大量进展，但迄今为止二维材料纳米 孔仍未实现被用于纳米孔测序的初衷一一单碱基分辨 率的检测. 造成此现状的原因有很多. 首先, 与所有纳 米孔一样, $\mathrm{DNA}$ 等生物分子在纳米孔内的构象波动很 大并且通过二维材料纳米孔的速率过高, 甚至超出了 现有设备带宽所能检测的范围，是限制纳米孔(包括传 统纳米孔和二维材料纳米孔)检测能力的关键原因. 此 外，对由少数层甚至单层二维材料制成的纳米孔而言， 二维材料纳米孔本身更易受周围溶液环境影响从而引 起结构波动导致额外的低频噪声, 这也会对识别的准 确性产生严峻的挑战. 围绕上述问题, 本文将梳理二维 材料纳米孔领域发展 10 年以来的重要进展，主要以计 算和模拟研究为主, 同时覆盖重要的实验进展. 在此基 础上, 总结和讨论了该领域面临的挑战, 并提出可能的 解决方案以指导后续研究工作.

\section{2 计算和模拟研究方法}

占据纳米孔的分子干扰离子正常通过纳米孔是所 测离子阻塞电流、膜内横向电流等检测信号的起源. 因此, 对孔内分子的动力学行为及其原子尺度传输过 程中的认识能为纳米孔器件的检测性能优化提供重要 指导. 然而, 常用实验观测工具, 包括原子力显微镜 (atomic force microscopy, AFM)、透射电子显微镜 (transmission electron microscope, TEM)、X射线衍射 (X-ray diffraction, XRD) 等很难在实验中直接观测溶液 环境下纳米孔中小分子、聚合物的动力学和这些分子 的迁移过程. 而分子动力学 (molecular dynamics, MD)等 计算机模拟手段可以直接追踪纳米孔中每个待测分 子、离子和水分子的运动轨迹, 因此可模拟DNA分子 跨越纳米孔的动力学传输过程并计算相应离子电流. 此外, 密度泛函理论(density functional theory, DFT)等 量子力学计算方法通过计算电子体系的性质来研究分 子和凝聚态的特性, 因此能准确考虑生物分子与二维 材料纳米孔的相互作用; 与非平衡格林函数结合后还 可计算出含纳米孔的二维材料纳米带内的横向电导或 电流. 下面简要介绍常用的服务于纳米孔传感器件研 制的计算和模拟研究方法.

\section{1 经典分子动力学模拟}

基于经验势函数的经典分子动力学是一种广泛用
于生物、材料和纳米体系的计算机模拟方法. 分子动 力学可以模拟飞秒至微秒时间尺度内, 由几十万甚至 几百万个原子组成的复杂体系的运动. 通过给定每个 原子初始位置和电荷建立系统模型后(图2(a))，计算机 根据经验势描述的原子间相互作用求解牛顿运动方程 得到体系随时间的动力学演化过程，即原子运动轨迹. 通过该轨迹，可以直接得到每一个粒子的坐标与速度 等微观量，也可经统计得到体系的温度、压强、热容 等宏观量. 此外, 我们可以直接根据离子的运动轨迹来 计算离子电流 ${ }^{[20]}$, 即

$I(t)=\frac{1}{\Delta t L} \sum_{i=1}^{N} q_{i}\left(Z_{i}(t+\Delta t)-Z_{i}(t)\right)$,

其中, $q_{i}$ 和 $Z_{i}$ 分别为离子 $i$ 的电荷和 $z$ 坐标. $N$ 代表总离子 数, $L$ 表示模拟系统在电场方向的长度. $\Delta t$ 是轨迹中两 帧之间的时间间隔. 分子动力学模拟可以较为精确地 描述纳米孔体系中的离子和生物分子等物质在电场下 穿过纳米孔的运动过程. 但是, 经典分子动力学往往不 考虑电荷转移, 一般无法描述化学键的生成或断裂, 也 不能描述外场等情况下的极化效应. 然而, 该方法能处 理的体系较大，有助于所得结果与实验数据的直接对 比. 常用分子动力学软件包括NAMD、GROMACS、 LAMMPS等.

\section{2 量子力学计算}

基于密度泛函理论的量子力学计算能准确预测体 系的原子结构和力学、电学、光学等一系列性质. 它 根据原子核和电子相互作用的原理及其基本运动规律, 运用量子力学原理，经过一系列近似处理后直接求解 薛定谔方程. 因此体系内原子间相互作用的计算不依 赖于任何经验势, 精度很高, 但能处理的体系较小. 用 量子力学计算纳米孔体系时, 可准确得出DNA等生物 分子与纳米孔的相互作用，例如，能获得分子(如核苷 酸分子)在孔内的局部最优构型．然而，由于其高昂的 计算成本, 通常只能处理包含数百个原子的系统, 所以 计算模型中往往忽略溶液中的水分子和离子, 如图2(b) 所示. 但是, 由于生物分子的结构和功能受溶液影响很 大，因此这一妥协可能会导致生物分子结构与真实场 景下截然不同. 此外, 当基于量子力学方法进行分子动 力学计算(即量子分子动力学)时, 时间尺度通常在皮秒 量级，所以不能用于DNA等生物分子穿过纳米孔的过 程等时间尺度较大的计算. 常用量子力学计算软件包 
(a)

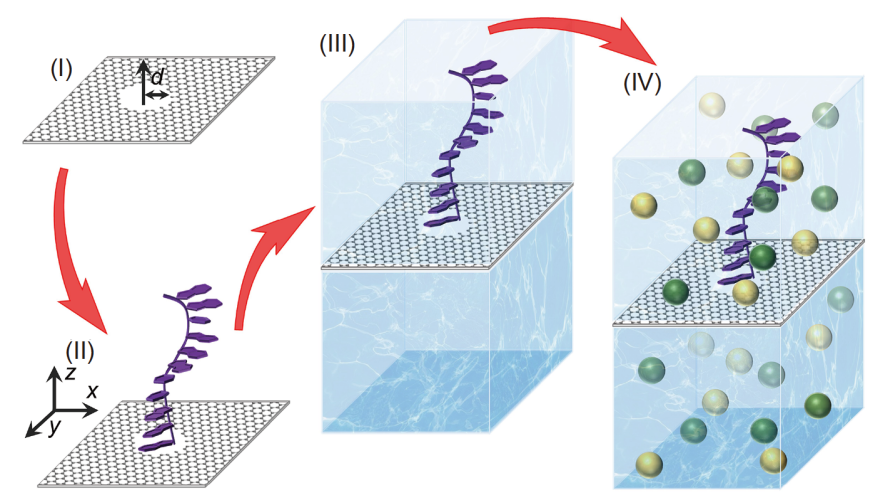

(b)

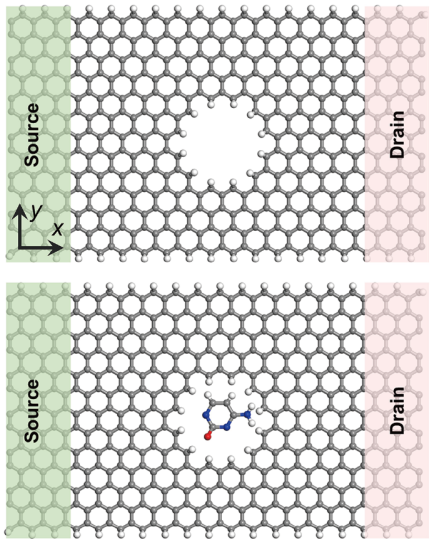

图 2 (网络版彩色)纳米孔器件计算和模拟模型的建立过程示意图. (a) 用于分子动力学模拟的全原子模型建立流程图: ( I ) 通过删除石墨烯层 特定范围内的原子来构建纳米孔; ( II ) 加人DNA等待测物至孔口处; (III) 将DNA-纳米孔复合结构浸人水溶液中; (IV) 向水溶液中添加适当浓度 的离子, 完成建模. (b) 用于横向电流/电导计算的石墨烯条带纳米孔模型. 在开孔的石墨烯条带左右两侧施加电压即可得到开孔状态的横向电 流. 若在孔内放人单个碱基, 即可得到碱基存在时的电流, 用于碱基识别

Figure 2 (Color online) Schematic diagram showing the procedure for building computational models of nanopore devices. (a) Flow chart of building a molecular dynamics simulation model: ( I ) A nanopore is constructed by deleting certain carbon atoms in graphene; (II) a DNA molecule is then added to the entrance of the nanopore; (III) the DNA-nanopore complex is immersed in a water solution; (IV) ions are added into the water solution to reach a desired salt concertation. (b) Models for transverse current/conductance calculation of graphene nanoribbon containing nanopores. The transverse current of open-pore state can be obtained by applying a voltage bias to sides of a device containing a graphene nanopore created from a single-layered graphene nanoribbon. When a single nucleobase is placed inside the nanopore, the calculated/measured transverse current can be used, in principle, for nucleotide recognition

括VASP和SIESTA等.

非平衡格林函数(non-equilibrium Green's function, NEGF)方法是一种研究纳米器件中量子输运效应的数 学工具. 该方法与密度泛函理论结合时, 能直接计算石 墨烯等二维材料纳米带的电子输运性质，并得到给定 偏压下通过二维材料纳米孔-生物分子复合构型的横 向电导或电流 ${ }^{[21]}$, 即:

$I\left(V_{\mathrm{b}}\right)=\frac{2 e}{h} \int_{\mu_{\mathrm{R}}}^{\mu_{\mathrm{L}}} T\left(E, V_{\mathrm{b}}\right)\left[f\left(E-\mu_{\mathrm{L}}\right)-f\left(E-\mu_{\mathrm{R}}\right)\right] \mathrm{d} E$,

其中, $h$ 是普朗克常数. $T\left(E, V_{\mathrm{b}}\right)$ 为在外加电压 $V_{\mathrm{b}}$ 下, 电子 在能量 $E$ 处从左电极人射到右电极的透射概率. $f\left(E-\mu_{\mathrm{L}}\right)$ 和 $f\left(E-\mu_{\mathrm{R}}\right)$ 分别是左右两个电极上电子的费米-狄拉克 分布. 一般用SIESTA软件包中集成的TransSiesta模块 等软件来计算电导.

\section{3 基于离子电流测量的二维材料纳米孔器件}

\section{1 石墨烯纳米孔}

基于 $\mathrm{MspA}^{[5]}$ 和 $\mathrm{CsgG}^{[22]}$ 等生物纳米孔, 人们已经能 通过读取离子电流信号来进行DNA测序. 这两种生物 纳米孔在结构上有一个共同的特点：孔内均存在一个 厚度与 DNA中两相邻碱基的距离相当的极短收缩
$区^{[23]}$. 因此，当DNA分子通过纳米孔时，在任一时刻仅 处于该收缩区内的单个碱基会对流过纳米孔的离子电 流产生阻断, 从而有效提高了纳米孔的检测分辨率, 大 大降低后续信号分析的难度. 与之形成鲜明对比的是, 多数天然存在的生物孔和人为构筑的固态孔的孔道区 域一般较为狭长, 有的甚至没有单个明显的收缩区, 因 此位于孔内的多个碱基同时影响所得离子电流信号, 造成信号分析非常困难 ${ }^{[23,24]}$. 基于超薄(甚至为单原子 层厚度)二维材料加工而成的纳米孔具有与 $\mathrm{MspA}$ 和 $\mathrm{CsgG}$ 蛋白纳米孔的极短收缩区“神似”的孔道结构，都 能够一次只容纳单个碱基，因此有望拥有与生物孔类 似的高分辨率.

仅有单原子层厚度(约 $0.34 \mathrm{~nm}$ )的石墨烯自从 2004 年被发现以来，由于其超高的强度、韧性、可塑性、 优异的导热导电性以及离子不可穿透等性质受到材 料、物理、力学、化学等众多学科研究人员的广泛关

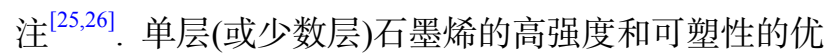
点恰巧解决了蛋白质和生物膜材料强度低、耐久性差 以及氮化硅等固态膜材料厚度大等先天弊端. 2010年, Golovchenko课题组 ${ }^{[12]}$ 、Drndic课题组 ${ }^{[13]}$ 和Dekker课题 组 ${ }^{[14]}$ 独立进行了DNA通过石墨烯纳米孔的实验，所采 用纳米孔实验装置也较为相似：在被硅片框架支撑的 
氮化硅膜的大孔上再覆盖一层含有单个纳米孔的石墨 烯, 纳米孔直径范围为 2 40 nm, 如图3(a)所示. 溶液中 没有DNA分子时, 所得纳米孔开孔电导(open-pore con- ductance)为恒定值(图3(b) $)^{[14]}$. Golovchenko课题组 ${ }^{[12]}$ 发 现单层石墨烯纳米孔的开孔电导与其直径近似线性相 关, 而Dekker课题组 ${ }^{[14]}$ 则认为开孔电导与直径的平方

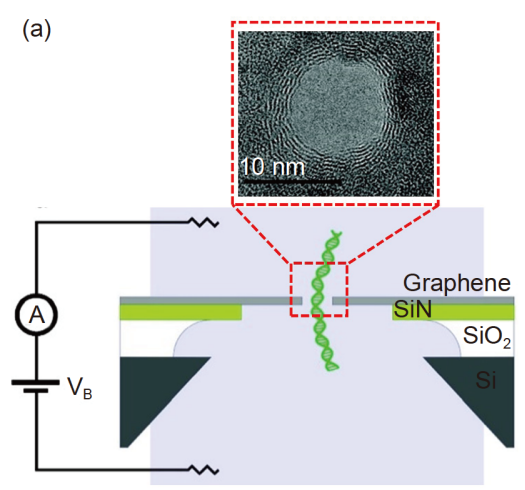

(b)

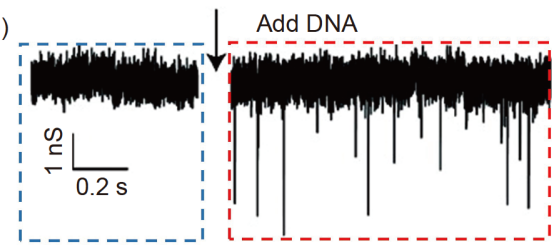

(c)

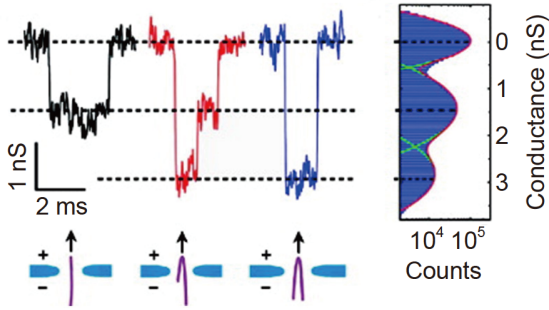

(d)

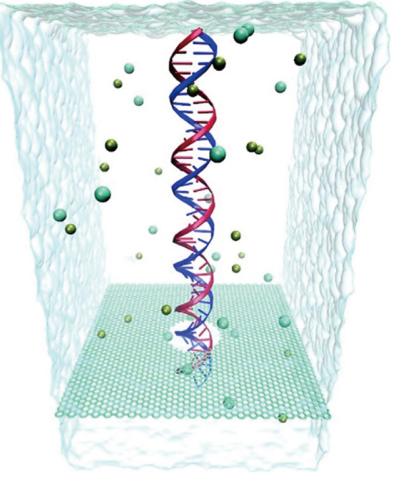

(e)

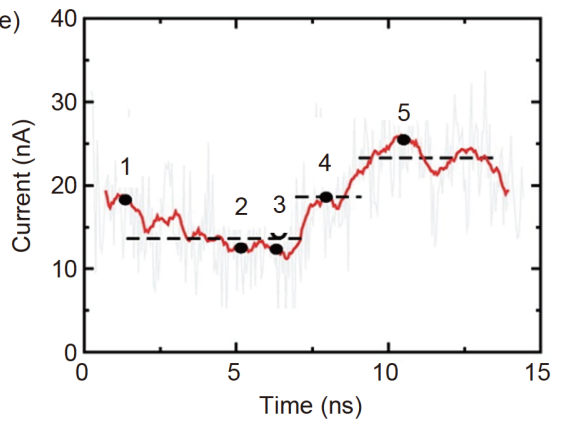

(f) 1
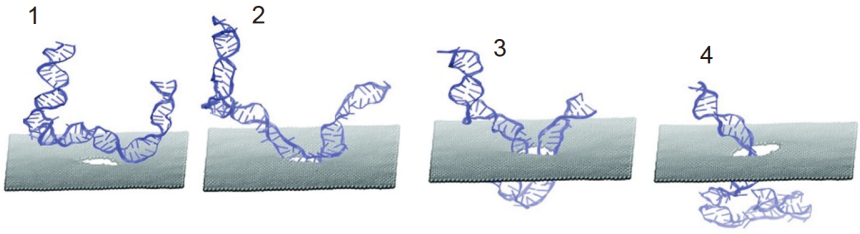

5

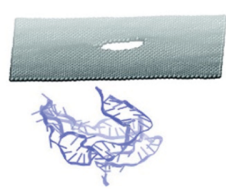

图 3 (网络版彩色)石墨烯纳米孔器件. (a) 石墨烯纳米孔实验装置示意图. 含有纳米孔的石墨烯片被覆盖在硅片框架支撑的氮化硅膜的大孔 $上^{[13]}$, Copyright (C 2010 American Chemical Society. (b) $22 \mathrm{~nm}$ 直径石墨烯纳米孔的离子电导. 左图为开孔状态(无DNA)的电导, 右图为溶液中的 多条双链DNA穿过纳米孔时的电导 ${ }^{[14]}$, Copyright (C) 2010 American Chemical Society. (c) 左侧为DNA以“未折叠”(左), “部分折叠”(中)和“全部折 叠”(右)状态通过纳米孔时的特征电导信号, 右侧为DNA穿过纳米孔时的电导值统计直方图 ${ }^{[14]}$. (d) DNA穿过单层石墨烯纳米孔的分子动力学模

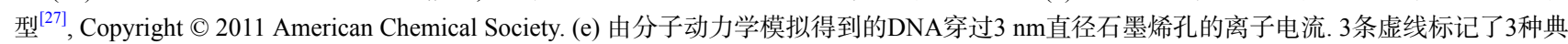
型电流水平 ${ }^{[27]}$. (f) DNA穿过纳米孔过程的模拟截图 ${ }^{[27]}$

Figure 3 (Color online) Graphene nanopore devices. (a) Schematic of a graphene nanopore device adopted in experiments. A sheet of graphene containing a nanopore is suspended over an aperture of a $\mathrm{SiN}_{x}$ layer on a Si substrate chip ${ }^{[13]}$, Copyright $\odot 2010$ American Chemical Society. (b) Ionic conductance of a 22-nm-diameter graphene nanopore. The left and right panels show the open pore conductance and blockade conductance corresponding to the translocation of dsDNA through the nanopore, respectively ${ }^{[14]}$, Copyright $\subset 2010$ American Chemical Society. (c) The left panel shows translocation events of nonfolded (left panel), partially folded (middle panel), and fully folded (right panel) DNA molecules, while the right panel shows conductance histogram ${ }^{[14]}$. (d) MD simulation model of DNA translocation through a graphene nanopore ${ }^{[27]}$, Copyright (C) 2011 American Chemical Society. (e) Ionic current recorded during MD simulation of DNA translocation through a 3-nm-diameter nanopore. The dashed lines highlight three typical current levels ${ }^{[27]}$. (f) Simulation snapshots showing DNA translocation through the nanopore ${ }^{[27]}$ 
成正比. 当溶液中加人DNA分子后, DNA在电场驱动下 进人纳米孔并阻止离子正常通过, 形成电流阻塞, 此时 纳米孔的电导会出现类似于“针尖”状的下降峰(图3 (b) $)^{[14]}$. 进一步对DNA过孔的每一个电导信号(单个下 降峰)放大后进行统计分析, 得到如图3(c)所示的3种典 型电导信号. 这3种信号分别对应DNA穿过纳米孔时的 3种构型状态，即“不折叠”、“部分折叠”和“全部折

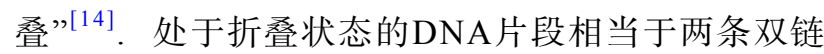
DNA，因此进人纳米孔时电导会出现相对不折叠状态 更大幅度的下降 ${ }^{[14]}$. 通过对电导降幅的进一步统计发 现，DNA以未折叠状态通过石墨烯纳米孔时与相同条 件下通过氮化硅固态纳米孔时的电导降幅一致 ${ }^{[12,14]}$. 除了电导降幅相同, DNA穿过石墨烯纳米孔的时间, 即 阻塞电流持续时间，也与相同条件下通过固态纳米孔 的时间相近 ${ }^{[12,14]}$. 个别持续较长的阻塞电流信号是由 于DNA与石墨烯的强相互作用所致. 但相同条件下石 墨烯纳米孔的离子电流噪声要远大于固态孔, 这与石 墨烯薄膜的结构波动等因素有关.

实验工作中，因为纳米孔尺寸太小且DNA等生物 分子穿过孔的时间十分短暂, 所以很难直接观察生物 分子穿过纳米孔的动态过程, 并且难以揭示在此过程 中DNA的动力学及其与孔壁的相互作用. 此外, 在原 子尺度精准控制纳米孔的结构也是一个实验方面的挑 战, 例如, 如何确保纳米孔具有统一的孔径和形状? 上 述这些问题导致不同实验结果间很难直接进行对比. 这些挑战在一定程度上可以通过计算机模拟来克服. 在二维材料纳米孔被提出之前, 分子动力学模拟已被 广泛地应用于固态和蛋白纳米孔体系的研究，包括揭 示纳米孔传输机制或协助纳米孔的设计等 ${ }^{[20,23,24,28,29]}$. 2011年，美国伊利诺伊大学厄巴纳香槟分校Schulten课 题组 ${ }^{[27]}$ 率先用分子动力学模拟重现了与实验报道类似 的双链DNA穿过石墨烯纳米孔的动力学过程. 他们依 据实验中的纳米孔装置建立了原子尺度计算机模型, 但出于降低计算量等考量未包含用于支撑的氮化硅膜 和硅片. 如图3(d)所示, 用一片包含单个纳米孔的石墨 烯把充满氯化钾溶液的模拟盒子分隔为上下两个腔室. 为了使DNA分子在有限的模拟时间内被纳米孔捕获, 在初始构型中DNA下端被置于孔口附近. 他们首先分 析了电场作用下沿纳米孔轴向的静电势分布, 发现静 电势都在孔口附近出现突然的下降，并且半径越小的 纳米孔，电势下降越剧烈。这一静电势变化特征与 $\mathrm{MspA}$ 蛋白质孔十分相近 ${ }^{[23]}$, 表明具有原子级厚度的二
维材料纳米孔在几何构造上具有接近性能优异的生物 纳米孔的先天优势. 进一步, 计算了DNA通过纳米孔时 的离子电流(图3(e)), 发现存在 3 个电流水平. 这 3 个电流 水平分别对应于开孔电流、单根DNA的阻塞电流、折 叠状的DNA(相当于 2 根DNA)的阻塞电流(图3(f) ${ }^{[27]}$. 该 发现与上述DNA穿过纳米孔实验中发现的3个电流(电 导)水平类似 ${ }^{[13,14,27]}$. 此外, 模拟结果表明, 单层石墨烯 纳米孔的开孔电阻与纳米孔直径平方的倒数成正

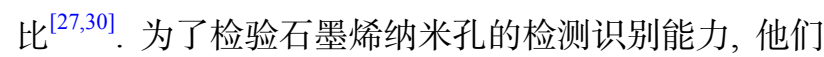
对比了分别由 20 个AT和 20 个 GC碱基对构成的 2 个双链 $\operatorname{DNA}\left(\right.$ 即poly $(\mathrm{A}-\mathrm{T})_{20}$ 和poly $(\mathrm{G}-\mathrm{C})_{20}$ ) 穿过直径为 $2.4 \mathrm{~nm}$ 的 纳米孔的阻塞电流, 发现由于 $\mathrm{AT}$ 碱基对的氢键比 $\mathrm{GC}$ 碱 基对少 1 个, 所以组成poly(A-T $)_{20}$ 的 2 条链间的氢键更容 易在强电场作用下被拉伸至断裂，导致两条链会局部 分开, 因此poly $(\mathrm{A}-\mathrm{T})_{20}$ 的阻塞电流要大于 $\operatorname{poly}(\mathrm{G}-$ C) ${ }_{20}^{[27]}$.

通过所得离子电流直接读取DNA链中4种碱基的 排列顺序是纳米孔测序的目标. 从测序信号解读等角 度来看, 相较于碱基成对出现的双链DNA, 对单链 DNA进行单个碱基直接读取可能是一个更好的选择. 但是, 单链DNA过孔时构象更加不稳定, 其在孔内的波 动会造成额外的电流噪声, 会给单链DNA测序带来很 多挑战. Wells等人 ${ }^{[31]}$ 通过分子动力学模拟系统地研究 了单链DNA通过石墨烯纳米孔的动力学过程和相应离 子阻塞电流. 他们首先发现单链DNA非常倾向于吸附 在石墨烯表面，在外加驱动电场作用下，导致单链 DNA采取单核苷酸逐个通过的方式穿过石墨烯纳米 孔. 该过程与单链DNA在聚合酶分子马达驱动下通过 生物孔的过程非常相似，暗示着石墨烯纳米孔可能拥 有潜在的与生物孔体系相近的DNA运动控制能力. 进 一步，他们发现DNA碱基在孔内的空间取向显著影响 离子电流. 然而, 对DNA构型的大量统计表明, 碱基通 常会趋于特定的空间取向, 这种取向的稳定性会降低 由DNA构象变化引起的噪声, 有助于测序. 基于原子 分辨率布朗动力学(atomic-resolution Brownian dynamics，ARBD)方法，Wells等人 ${ }^{[31]}$ 计算了每种碱基在 不同取向下的阻塞电流，发现不同碱基对应的电流具 有一定的统计学差异. 这些结果表明位于纳米孔内碱 基的尺寸和构型等因素能显著影响阻塞电流. 以上影 响阻塞电流的方式可以归结于位于孔内的DNA原子的 “空间排斥”效应. 此外, 通过计算机模拟发现，除孔内 碱基以外, 孔附近 $1.5 \mathrm{~nm}$ 范围内的碱基 ${ }^{[32]}$ 和带负电的 
DNA对离子的“电排斥”效应 ${ }^{[33]}$ 也会显著影响通过纳米 孔的离子阻塞电流. 进一步, Ma课题组 ${ }^{[34]}$ 发现, 当石墨 烯纳米孔边缘为氢修饰时, 阻塞电流差异主要源自碱 基与离子间的静电相互作用差异; 当纳米孔边缘为羟 基修饰时，核苷酸的位置、周围离子的过孔时间及静 电作用都会对阻塞电流产生影响. 除了对阻塞电流下 降幅度进行分析外，对不同碱基阻塞电流持续时间的 分析也有望用于测序. Shi等人 ${ }^{[35]}$ 发现分别由 15 个A、

$\mathrm{T} 、 \mathrm{C}$ 和 $\mathrm{G}$ 碱基组成的 4条DNA单链穿过石墨烯纳米孔 的时间顺序为 $\operatorname{poly}(\mathrm{G})_{15}>\operatorname{poly}(\mathrm{C})_{15}>\operatorname{poly}(\mathrm{T})_{15}>\operatorname{poly}(\mathrm{A})_{15}$.

石墨烯纳米孔的另一个优点是通过改变石墨烯层 数可以精确控制孔道长度. 虽然石墨烯单层具有理论 上最高的空间分辨率, 但一系列模拟结果表明, 增加层 数会减小DNA过孔时的速度并提高信噪比 ${ }^{[36 \sim 38]}$. 此外, 单链DNA会紧紧黏附在单层石墨烯表面，导致其在弱 电场下很难通过纳米孔; 而在强电场作用下, 单链 DNA的多个碱基会在极短时间内同时“跳跃”通过石墨 烯纳米孔, 导致不能捕捉到单碱基分辨率的信号 ${ }^{[31]}$. 当 石墨烯的层数增加到3层时, DNA碱基较容易通过且很 少发生“跳跃”现象, 也就是说, 单链DNA以上文提到的 单核苷酸逐个过孔的方式有序穿过纳米孔 ${ }^{[31]}$. 此外, Wells等人 ${ }^{[31]}$ 还发现采用3层石墨烯可以降低孔内DNA 的构型波动, 因此他们认为 3 层石墨烯是纳米孔DNA测 序的最优厚度.

生物分子被纳米孔捕获并进入纳米孔是进行后续 检测分析的必要条件. Sathe等人 ${ }^{[27]}$ 发现DNA只有在孔 口附近才容易被纳米孔捕获。造成石墨烯纳米孔低 DNA捕获率的原因是仅在孔口附近存在着较明显的静 电势变化(即较强的电场). 一般来说, 可通过增加外电 场的强度来提升纳米孔的捕获率. 然而, Wilson和Aksimentiev ${ }^{[39]}$ 的模拟结果表明，过强的电场会造成石墨烯 纳米孔内异常高的水压强, 进而阻止DNA进人纳米孔, 因此过大的电场反而会降低捕获率. 该发现意味着选 取合适的外电场(即偏压)对二维材料纳米孔器件的分 子捕获而言非常关键.

\section{2 其他一维材料纳米孔}

除石墨烯外，二硫化钼和六方氮化硼等其他二维 材料也受到纳米孔领域研究人员的广泛关注. 与仅为 单原子厚度的单层石墨烯不同，二硫化钼是由 2 层 $\mathrm{S}$ 原 子平面之间夹着 1 层 Mol原子平面所组成的. 其单层厚 度约为 $0.7 \mathrm{~nm}$, 与 2 3层石墨烯相当. 此外, 与边缘只由
单种原子(碳)组成的石墨烯纳米孔不同, 不同尺寸和形 状的二硫化钼纳米孔可能拥有截然不同的边缘组成, 包括孔边缘只暴露 $\mathrm{Mo}$ 原子, 只暴露 $\mathrm{S}$ 原子或同时暴露 Mo、S 原子等. 这为控制纳米孔结构以调控其性质提 供了更丰富的选择.

2014年, Liu等人 ${ }^{[15]}$ 首先报道了DNA穿过二硫化锄 纳米孔的实验研究. 所用实验装置与石墨烯纳米孔实 验相似：一片包含单个纳米孔的二硫化钼被覆盖在氮 化硅膜的大孔上，如图4(a)所示. 他们发现 $\lambda$-DNA穿过 $20 \mathrm{~nm}$ 直径二硫化钼单层纳米孔时电导的下降幅度非 常明显(图4(b)), 远超同一直径但厚度为 $20 \mathrm{~nm}$ 的氮化 硅纳米孔, 且二硫化钼纳米孔具有较高的信噪比 ${ }^{[15]}$. 此 外, 与石墨烯纳米孔类似, DNA也会以不同折叠状态穿 过二硫化钼纳米孔，但与石墨烯纳米孔不同的是，Liu 等人 ${ }^{[15]}$ 认为DNA有时会以螺旋状的形式“撞击”到纳米 孔, 造成更强的离子电流阻塞(图4(b)).

很多学者也通过分子动力学模拟了DNA穿过二硫 化钼纳米孔的过程 ${ }^{[16,17,40]}$ (图4(c)). 图4(d)的离子电流曲 线表明, DNA穿过纳米孔时电流变化非常明显 ${ }^{[17]}$. Farimani等人 ${ }^{[16]}$ 的分子动力学模拟结果显示相同条件下 不同碱基在二硫化钼纳米孔内的离子电流由大到小的 顺序为 $\mathrm{AT}>\mathrm{G}>\mathrm{T}>\mathrm{CG}>\mathrm{C}$. 他们还发现二硫化钿孔离 子电流的信噪比为 15.02 , 远高于相同条件下相同半径 石墨烯孔的信噪比 $3.32^{[16]}$. 此外, 他们还用第一性原理 计算了DNA碱基与不同边缘二硫化钿纳米孔的相互作 用, 发现碱基与边缘仅暴露 $\mathrm{Mo}$ 原子的纳米孔的相互作 用最强, 这种强相互作用可能会有助于纳米孔识别不 同碱基 ${ }^{[16]}$.

与DNA在石墨烯表面的黏附会阻止DNA穿过纳米 孔甚至会堵塞纳米孔截然不同，模拟 ${ }^{[16,40]}$ 和实验 ${ }^{[15]}$ 都 发现, DNA在二硫化钼表面更加不易发生黏附. 如图4 (e)所示，分子动力学模拟表明DNA位于石墨烯表面附 近时会迅速开始黏附，而在二硫化钼表面的黏附不仅 相对较慢, 且最终黏附的碱基数量也远小于前者. 也就 是说, 与石墨烯相比, 二硫化钼表面较为亲水, 与DNA 之间的疏水作用力较弱，因此不必对其表面进行以减 少DNA黏附为目的的亲水处理.

与石墨烯相似，六方氮化嗍也具有六方层状结构, 但每一层都由硼和氮原子交替排列组成 ${ }^{[41]}$. 2013年, Yu课题组 ${ }^{[18]}$ 首先进行了DNA穿过单层氮化硼纳米孔 的实验. 他们在单层氮化嗍上构筑了不同半径的准圆 形纳米孔，并观察到与DNA穿过石墨烯纳米孔时相似 
(a)

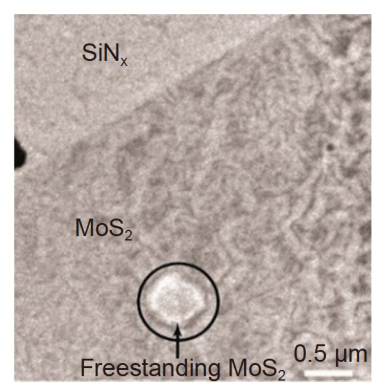

(c)
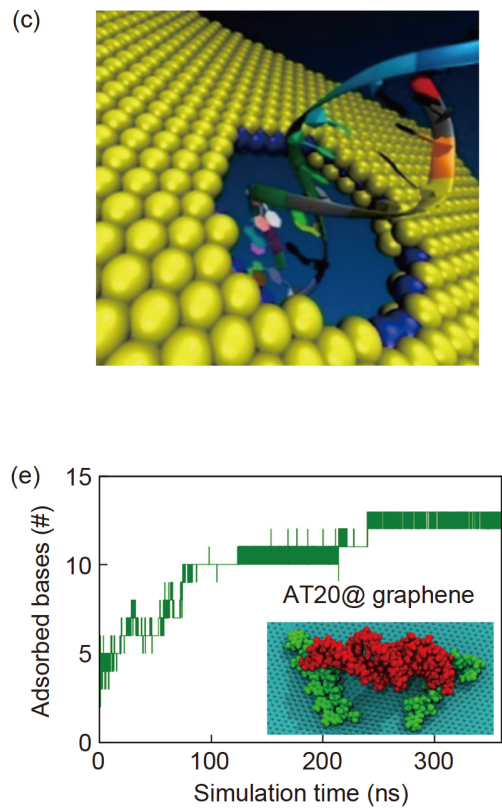

(b)

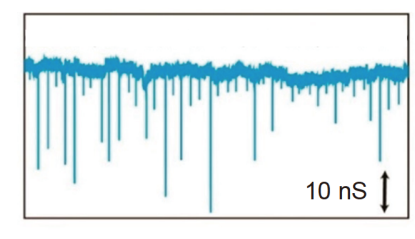

12

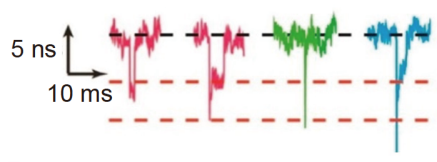

(d)
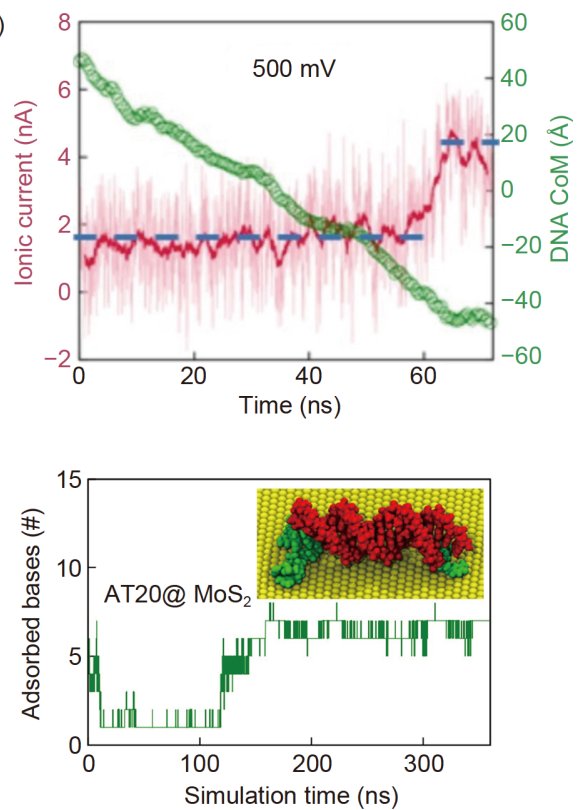

图 4 (网络版彩色)二硫化锄纳米孔器件. (a) 纳米孔膜系统的TEM照片. 二硫化锄位于氮化硅膜上方, 黑色圆圈标记了二硫化锄上的纳米孔 ${ }^{[15]}$, Copyright $\odot 2014$ American Chemical Society. (b) $\lambda$-DNA穿过直径为 $20 \mathrm{~nm}$ 的二硫化锄纳米孔的电导记录. 图片下部为DNA以“未折叠”(1)、“部 分折叠”(2)、“全部折叠”(3)以及“螺旋”(4)状态通过纳米孔时的电导 ${ }^{[15]}$. (c) DNA穿过二硫化钿纳米孔的模拟系统示意图 ${ }^{[16]}$, Copyright $\odot 2014$ American Chemical Society. (d) 模拟得到的双链DNA通过直径为 $2.4 \mathrm{~nm}$ 二硫化钿孔时的离子电流(线)和DNA分子的质心位置(圆圈, 沿膜法向) 随时间的变化 ${ }^{[17]}$, Copyright (0) 2017 Royal Society of Chemistry. (e) 双链DNA在石墨烯和二硫化钿表面吸附的对比模拟, 左图和右图分别表示 DNA吸附在石墨烯和二硫化钼表面上的碱基数随时间的演化 ${ }^{[40]}$, Copyright (C) 2017 Springer Nature

Figure 4 (Color online) $\mathrm{MoS}_{2}$ nanopore devices. (a) TEM image of a $\mathrm{MoS}_{2}$ sheet covering an aperture in a SiN $\mathrm{membrane}_{x} \mathrm{~A}$ nanopore in $\mathrm{MoS}_{2}$ is marked with the black circle ${ }^{[15]}$, Copyright (C) 2014 American Chemical Society. (b) Conductance trace of $\lambda$-DNA translocation through a MoS $\mathrm{D}_{2}$ nanopore (20 nm diameter). Examples of events of nonfolded (1), partially folded (2), fully folded (3) and coiled form (4) DNA molecules are shown in the bottom panel ${ }^{[15]}$. (c) Schematic of dsDNA translocation through the $\mathrm{MoS}_{2}$ nanopore ${ }^{[16]}$, Copyright (C) 2014 American Chemical Society. (d) Recorded ionic current (line) and the center of mass position of a dsDNA molecule in the direction perpendicular to the MoS ${ }_{2}$ (circles), as the DNA was translocated through a 2.4-nm-diameter $\mathrm{MoS}_{2}$ nanopore ${ }^{[17]}$, Copyright (C) 2017 Royal Society of Chemistry. (e) Evolution of the number of DNA bases adsorbed on graphene (left) and $\mathrm{MoS}_{2}$ (right) surfaces based on MD simulations ${ }^{[40]}$, Copyright (C) 2017 Springer Nature

的离子电流变化 ${ }^{[18]} .2017$ 年，Liu等人 ${ }^{[19]}$ 制备出了近乎 规则的三角形氮化硼纳米孔．相比于石墨烯和二硫化 钿纳米孔(准圆形)不规则的边缘, 采用具有规则形状的 三角形氮化嗍纳米孔有利于保证纳米孔实验制备和器 件构筑的可重复性. 所用实验装置与前述二维材料纳 米孔实验类似(图 5(a)), 将含有三角形纳米孔的单层氮 化硼置于具有更大孔径的氮化硅孔上 ${ }^{[19]}$. 当DNA穿过 纳米孔时, 他们发现离子电流分布只有 1 个峰值, 但
DNA过孔时间分布却呈现一定的双峰特征 ${ }^{[19]}$ (图5(b)). 他们用分子动力学模拟为此提供了解释. 如图 5(c), (d) 所示, DNA会以两种状态穿过三角形的氮化嗍纳米孔: 一是DNA沿着孔中心轴附近穿过(along-axis), 另一种 是DNA沿着偏离孔轴并靠近三角形孔的一角附近穿过 (off-axis). 显然，这两种状态下DNA受到不同的阻力, 导致不同的过孔时间 ${ }^{[19]}$.

Liu等人 ${ }^{[19]}$ 的实验还对比了分别由 $\mathrm{A}$ 或 $\mathrm{C}$ 组成的单 


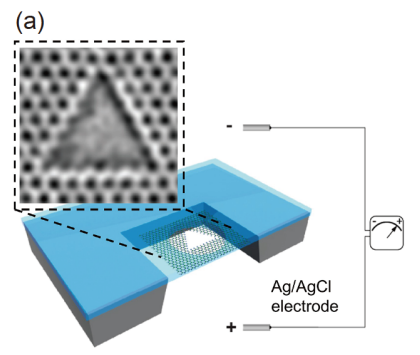

(c)
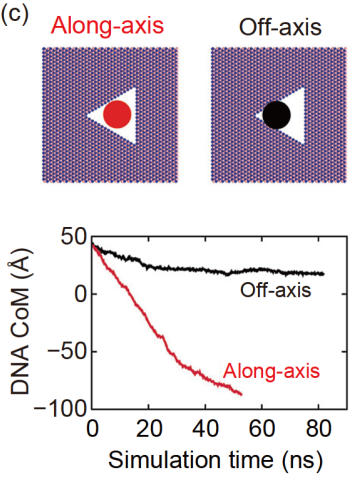

(b)

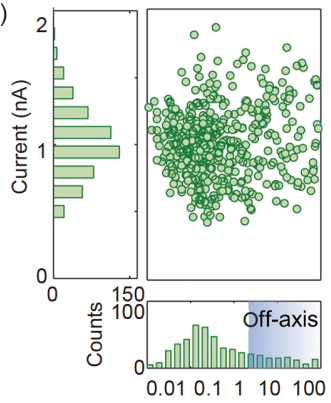

(d)

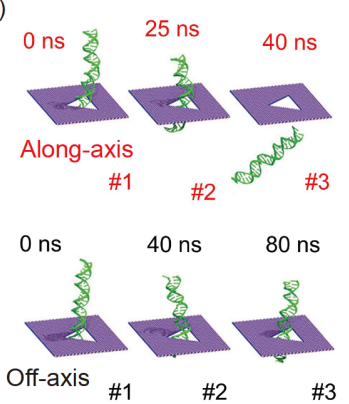

图 5 (网络版彩色)六方氮化嗍纳米孔器件. (a) 三角形氮化嗍纳米 孔膜系统的示意图, 其中单层氮化嗍置于氮化硅膜的孔上 ${ }^{[19]}$, Copyright (c) 2017 American Chemical Society. (b) DNA穿过纳米孔时的电 流变化值与过孔时间的分布图 ${ }^{[19]}$. (c) DNA穿过三角形纳米孔的分子 动力学模拟过程中, DNA沿着纳米孔中心轴(along-axis)和偏离孔轴 (off-axis)穿过纳米孔时, 其质心随时间的变化 ${ }^{[19]}$. (d) DNA穿过氮化 嗍纳米孔不同时刻的分子动力学模拟轨迹照片 ${ }^{[19]}$

Figure 5 (Color online) h-BN nanopore devices. (a) Schematic of a triangular h-BN nanopore membrane device, where a h-BN sheet is covered over an aperture in a $\mathrm{SiN}_{x}$ membrane ${ }^{[19]}$, Copyright (C) 2017 American Chemical Society. (b) Scatter plot of recorded current drop versus dwell time of DNA translocation through the nanopore ${ }^{[19]}$. (c) Change of the center of mass position of the dsDNA in the direction perpendicular to the membrane with respect to MD simulation time ${ }^{[19]}$. (d) Snapshots taken from simulations of the along-axis (top panel) and off-axis (bottom panel) dsDNA translocation through the h-BN nanopore ${ }^{[19]}$

链DNA通过三角形氮化硼纳米孔时的离子电流，发现 前者电流略高. $\mathrm{Gu}$ 等人 ${ }^{[42]}$ 的模拟则发现，由 40 个 $\mathrm{GC}$ 碱 基对组成的 DNA双链poly $(\mathrm{G}-\mathrm{C})_{40}$ 的阻塞电流大于由 AT碱基对组成的poly $(\mathrm{A}-\mathrm{T})_{40}$ 的阻塞电流，这一趋势与 石墨烯纳米孔中发现的相反.

\section{3 生物分子穿过二维材料纳米孔的运动控制}

尽管开展了大量研究，但迄今为止仍没有用二维 材料纳米孔成功实现DNA测序的实验报道. 其主要原 因在于, 其一, 二维材料纳米孔测序中不仅存在传统固 态膜的电流噪声，也存在石墨烯膜波动导致的额外噪 声; 其二, 与传统固态纳米孔所面临的问题一样, 二维

材料纳米孔也存在被检测物过孔速度太快、随机性较 大和构象波动等问题. 特别是对于二维材料纳米孔, 过 快的过孔速度导致其空间分辨率的优势完全没有在检 测中发挥出来. 在 $\mathrm{MspA}$ 等生物纳米孔器件中, 一般通 过解旋酶或聚合酶作为分子马达来控制DNA穿过纳米 孔的速度，使核苷酸逐个且缓慢地通过纳米孔 ${ }^{[5,22]}$. 生 物纳米孔成功用于DNA测序这一事实表明，分子马达 这一运动控制方式起到了关键作用. 然而, 将生物酶整 合到二维材料等固态纳米孔体系显然是一个较大的挑 战. 针对以上问题, 一些学者开始寻找其他方案来控制 被检测物穿过二维材料纳米孔的速度 $\left.{ }^{[43} 48\right]$ 和降低噪 声 $^{[49 \sim 52]}$.

利用分子动力学模拟，Shankla和Aksimentiev ${ }^{[46]}$ 发 现石墨烯表面碱基的构象对石墨烯内的电荷十分敏感, 单链DNA在带正电、带负电和不带电的石墨烯表面分 别呈现出“倾斜”(tilted)、“未绑定”(unbound)和“扁 平”(flat)构象. 他们还发现，相同跨膜电压但石墨烯电 荷量不同时，DNA通过纳米孔运动速度截然不同. 因 此，通过交替改变石墨烯的电荷量和跨膜电压的方向， 可以有效控制DNA分子在“穿过”、“停留”或者“退出” 纳米孔等不同的运动状态之间切换. Luan和Zhou ${ }^{[45]}$ 发 现，基于二硫化钼和石墨烯异质结，DNA会自发地从 低化学势的二硫化钼表面离开, 并跨越异质结上的纳 米孔移动到高化学势的石墨烯表面, 并且实现低速甚 至单碱基的输运. 另外, 利用石墨烯表面天然存在的台 阶状缺陷也可对单链DNA或RNA分子跨越纳米孔的运 动进行控制. Shankla和Aksimentiev ${ }^{[47]}$ 的模拟研究发现, 相同外力作用下DNA分子跨越石墨烯台阶(向上或者 向下)的运动速度明显小于其沿与台阶平行方向运动 (不跨越)的速度. 进一步, 他们在石墨烯表面人为构建 螺旋状台阶, 发现DNA分子在外力驱动下会沿着平行 于台阶的方向被引导至位于螺旋中心的纳米孔里 ${ }^{[47]}$. 除了对二维材料表面进行改造外, 对纳米孔边缘进行 调控也能控制生物分子跨越纳米孔的运动. $\mathrm{Si}$ 等人 ${ }^{[48]}$ 发现, 改变二硫化钼纳米孔边缘暴露的 $\mathrm{S}$ 原子和Mo原 子数目的比值能降低DNA的运动速率, 甚至能使其沿 相反方向运动(图6(a)). 对二维材料纳米孔系统中DNA 运动控制的研究近几年才刚刚起步, 且多处在理论探 索阶段, 鲜有实验报道.

除了控制被检测物的运动，降低纳米孔测序的电 流噪声是另一个重要挑战. 电流噪声分为高频和低频 噪声, 高频噪声在固态孔和二维材料孔中都存在, 其主 
(a)

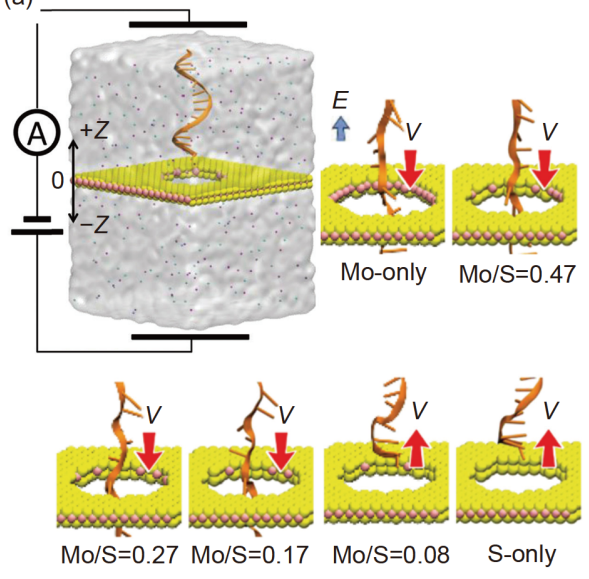

(b)

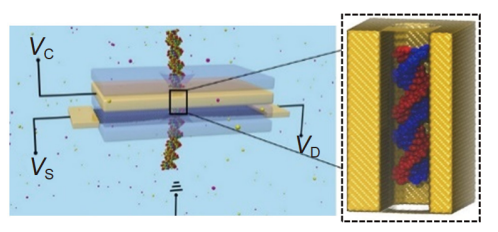

(c)

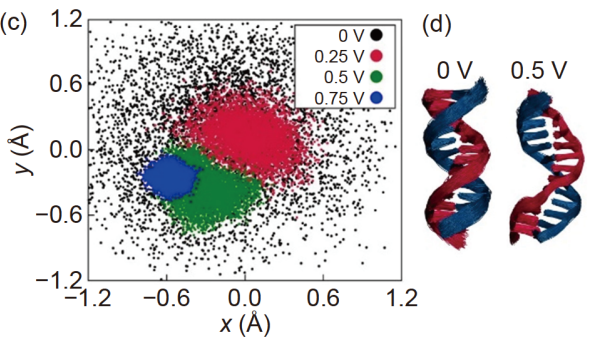

图 6 (网络版彩色)生物分子穿过二维材料纳米孔的运动控制. (a) 改变二硫化钼纳米孔边缘的Mo原子和S原子数目之比控制单链DNA穿过纳 米孔的运动 ${ }^{[48]}$, Copyright (C) 2018 Royal Society of Chemistry. (b) 多层膜堆叠组成的“三明治”结构纳米孔器件示意图. 可外加偏压的金属控制层 (外接 $V_{\mathrm{c}}$ )夹在两个氧化物绝缘层之间, 中间为用于传感的石墨烯 $\left(\text { 外接 } V_{\mathrm{s}}\right)^{[50]}$, Copyright (C) 2016 American Chemical Society. (c) 不同偏压作用下纳 米孔内双链DNA质心位置的散点图 ${ }^{[50]}$. (d) 0.5 V正电压下DNA分子的构型与无偏压时的对比, 此处的DNA构型图由大量不同时刻的DNA位置 重叠而得 ${ }^{[50]}$

Figure 6 (Color online) Control of biomolecular translocation through 2D material nanopores. (a) Control of the movement of ssDNA via the ratio between the number of Mo and S atoms at the edge of a $\mathrm{MoS}_{2}$ nanopore ${ }^{[48]}$, Copyright $(2018$ Royal Society of Chemistry. (b) Schematic of a typical sandwich-like nanopore device. A metallic control layer (with applied voltages, $V_{\mathrm{c}}$ ) is sandwiched between two insulating oxide layers, and a graphene membrane (with applied voltages, $V_{\mathrm{s}}$ ) is used to read biomolecules ${ }^{[50]}$, Copyright $\subset 2016$ American Chemical Society. (c) Scatter diagram showing center of mass positions of dsDNA during $20 \mathrm{~ns}$ simulation time under different voltages ${ }^{[50]}$. (d) Overlapped conformations of the dsDNA under voltage biases of 0 and $0.5 \mathrm{~V}^{[50]}$

要与介电层(即二维材料纳米孔系统中作为支撑作用 的氮化硅层)的厚度有关. 增加介电层的厚度, 如采用氮 化硅与石英堆积而成的支撑层，可有效降低高频噪声. 与高频噪声不同, 低频噪声在二维材料纳米孔中尤为 明显, 约为传统固态孔的 100 倍, 这是因为低频噪声主 要与二维材料面外刚度弱导致的膜波动和石墨烯表面 疏水引起的不完全润湿有关 ${ }^{[13,53]}$. 因此, 提高二维材料 的机械强度和亲水性是解决低频噪声问题的关键. 此 外, 除了减少背景噪声, 降低被分析物的构象变化以提 高电流信号的精度也是增强信噪比的一种方法. 有实 验工作发现，石墨烯与氧化铝组成“三明治”结构时，纳 米孔内的离子电流噪声水平更加接近于固态孔, 也显 著低于单层石墨烯纳米孔 ${ }^{[51]}$. 此外, 通过分子动力学模 拟, Qiu等人 ${ }^{[49]}$ 构建了以石墨烯为中心且由多层膜堆叠 组成的“三明治”结构的纳米孔器件. 如图6(b)所示, 除 用于传感的石墨烯层外, 还包括一层专门用于运动控 制的金属层. 如图6(c), (d)所示, 在正偏压作用下, DNA 分子在孔内的波动会明显降低 ${ }^{[49]}$. 除以上提及的方案 外, 还可通过二维材料多层堆叠 ${ }^{[53,54]}$ 或减少石墨烯未 被支撑部分的面积 ${ }^{[55]}$ 等途径来提高二维材料膜的机械 性能并降低低频噪声. 但需要注意的是, 增加层数或与
其他材料堆叠等方式可能会削弱石墨烯的厚度优势, 导致二维材料纳米孔失去了单碱基分辨率这一优点.

\section{4 基于其他测量途径的二维材料纳米孔器件}

由于碱基过孔速度太快且随机性高、构型波动较 大、电流噪声大等因素, 通过测量二维材料或传统固 态纳米孔的离子电流这一途径实现单碱基分辨率的测 序仍极具挑战. 因此, 研究人员开始寻求其他测量途径 来进行生物分子通过纳米孔时的高分辨率检测. 初步 的尝试包括测量生物分子过孔时的膜内横向电流或待 测物受到的阻力信号等.

\section{1 膜内横向电流}

不同于绝缘的氮化硅等传统固态膜, 石墨烯、二 硫化钼等二维材料一般为导体或半导体. 当将二维材 料裁剪成有限宽度的纳米带时, 其导电性与其边缘结 构(如手性)紧密相关. 以石墨烯为例, 扶手椅边缘 (armchair)的石墨烯纳米带为半导体, 而锯齿状边缘 (zigzag) 的纳米带呈现金属性 ${ }^{[56-59]}$. 因此, 除了检测生物分子通 过纳米孔时的离子电流, 还可测量二维材料膜在横向 电压作用下产生的膜内电流来进行生物分子的分 
析 $^{[21,60 \sim 62]}$. 其原理如图7(a)所示，在横向偏压作用下产 生在石墨烯面内流动的横向电流，当DNA等被检测物 进人纳米孔时, DNA碱基与石墨烯纳米孔的相互作用 会调节纳米带中的横向电流，后续对电流解析即可获 得DNA序列信息 ${ }^{[65]}$. 与此原理相近的方式还有通过测 量DNA穿过由二维材料组成的纳米㖓隙(nanogap)的隧 道电流(tunneling current)来进行DNA分析 ${ }^{[62,66-68]}$.

利用二维材料膜内横向电流来进行纳米孔单分子 检测的研究是从理论和计算预测开始的. 2010年, Nelson等人 ${ }^{[60]}$ 首先采用密度泛函理论提出了这一想法. 他 们将单个碱基放人单层石墨烯纳米孔内，并调整模型 中碱基在孔内的位置和取向，通过非平衡格林函数方 法耦合密度泛函理论计算了不同偏压下石墨烯纳米带 内的横向电流(电导). 结果表明, 孔内存在碱基时的横 向电流与开孔时差别很大(图7(b)), 初步表明通过测量 膜内横向电流来进行单分子检测理论上是可行的. Saha等人 ${ }^{[63]}$ 则提出利用锯齿状的金属性纳米带来大幅
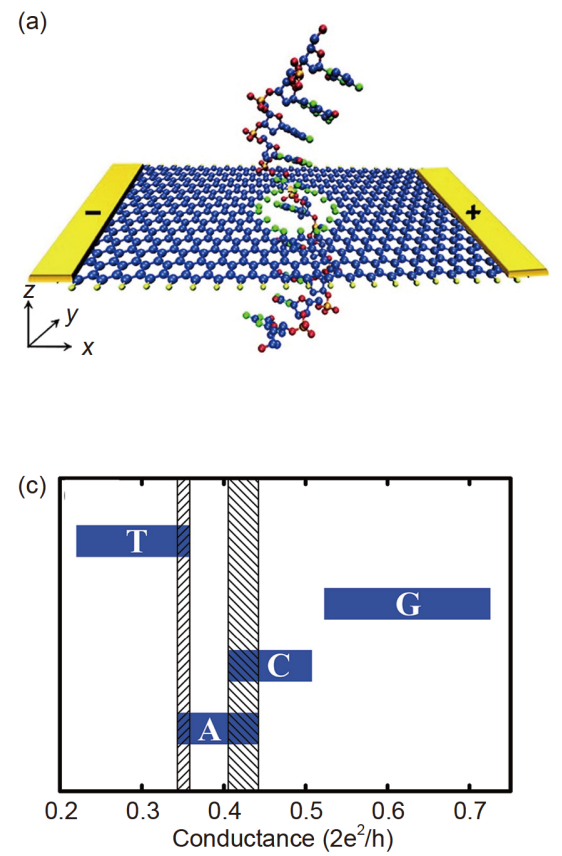

提高横向电流的数值 $(0.1 \mathrm{~V}$ 偏压下电流达微安量级), 这一发现有望大幅提升横向电流检测的信噪比. 他们 进一步研究发现不同碱基在纳米孔内时所得横向电导 有一定的差别，但是碱基构象变化导致每一个碱基对 应的电导并非恒定值，而在一定范围内波动(图7(c)). 此外，还发现纳米孔在石墨烯条带上的位置也会影响 横向电导, 并由此推断纳米孔位于条带边缘比在中心 更适合测序 ${ }^{[69]}$. 除了上述基于单层膜的纳米孔器件外, 研究者为了提高信噪比, 提出了各种新奇的膜结构. 例 如，Scheicher课题组 ${ }^{[70]}$ 在氮化硼纳米条带中间嵌人带 有纳米孔的石墨烯条带组成了混合膜; Sadeghi等人 ${ }^{[71]}$ 设计了含有纳米孔的双层“石墨烯结”; Ahmed等人 ${ }^{[72]}$ 利用多层石墨烯中每一层独立的横向电流信号来优化 碱基识别. 除识别碱基外, Balatsky课题组 ${ }^{[73]}$ 的理论预 测发现通过横向电流也能进行DNA甲基化的识别.

为了降低计算量，基于密度泛函理论的计算研究 工作通常忽略水和离子的存在，也不考虑DNA在纳米

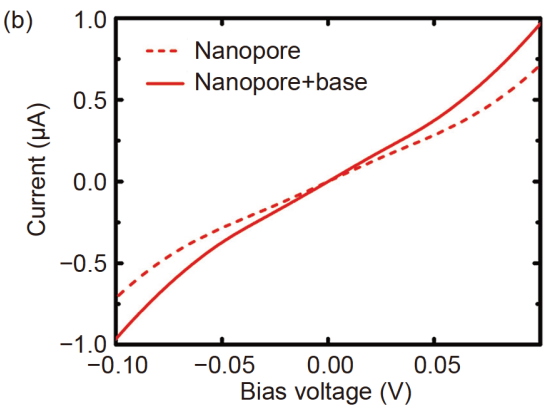

(d)

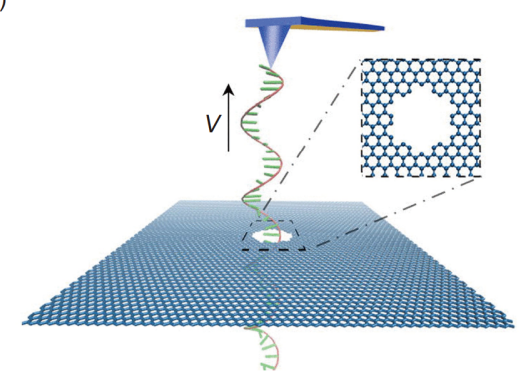

图 7 (网络版彩色)基于二维材料纳米孔的其他测量途径. (a) 通过测量石墨烯纳米带横向电流来检测DNA的原理图 ${ }^{[63]}$, Copyright ${ }^{\text {C) } 2012 ~}$ American Chemical Society. (b) 空纳米孔与被鸟嘌呤占据的纳米孔之间的横向电流对比 ${ }^{[63]}$. (c) 4种碱基在纳米孔内时的纳米带横向电导分布. 碱基的转动等构象变化导致电导波动, 阴影区域为电导重叠区 ${ }^{[63]}$. (d) 基于力测量检测DNA的原理图. AFM针尖拖动单链DNA穿过石墨烯纳米 孔, 根据不同碱基的受力不同可得到其序列 ${ }^{[64]}$, Copyright (C) 2012 AIP Publishing

Figure 7 (Color online) Other detection approaches for 2D material nanopores. (a) Schematic of transverse current measurement for detecting DNA based on a graphene nanoribbon with a nanopore ${ }^{[63]}$, Copyright $(\underset{2}{2012}$ American Chemical Society. (b) Transverse current of the graphene nanoribbon with an empty nanopore and an guanine-occupied nanopore ${ }^{[63]}$. (c) Transverse conductance of the graphene nanoribbon with a nanopore occupied by four different nucleobases. Conformation change (e.g., rotation) of nucleobases leads to the fluctuation of conductance, and the shaded regions represent the overlapping region of conductance ${ }^{[63]}$. (d) Schematic of DNA detection with measured force when pulling DNA through a graphene nanopore. The tip drags the ssDNA through the graphene nanopore, during which the DNA sequence could potentially be read out though the measured force signals $^{[64]}$, Copyright (C) 2012 AIP Publishing 
孔中的构型变化. 为了弥补这一缺陷, 一些课题组采用 计算量更低的紧束缚模型与非平衡格林函数方法结合 来处理横向电流/电导的计算. 他们所采用的原子模型 一般提取自DNA穿过纳米孔的分子动力学模拟过程中 的模拟体系，因此该模型考虑了DNA在真实溶液环境 下的构型波动 ${ }^{[21,74 ~ 77]}$. 采用该方法, Schulten课题组 ${ }^{[21]}$ 发现石墨烯纳米带的边缘形状、载流子浓度以及纳米 孔的位置和半径都会影响横向电导. 此外, 他们将普通 石墨烯纳米带与具有量子点接触(quantum point contact, QPC)边缘结构的纳米带进行了比较, 发现量子点 接触结构比扶手椅边缘的纳米带表现出更大的灵敏度. 进一步, 他们发现DNA在孔内的构象变化会对横向电 流产生巨大影响 ${ }^{[75,76]}$, 并提出可通过拉伸DNA的方式 减少构象波动，提高横向电流检测的分辨率和准确 性 ${ }^{[49]}$.

除理论和计算工作外，2013年，Traversi等人 ${ }^{[62]}$ 首 次在实验中同时记录了DNA穿过石墨烯条带上的纳米 孔时的离子电流和纳米带中的横向电流, 证明这一思 路在实验上是初步可行的. 随后, Puster等人 ${ }^{[78]}$ 和Heerema等人 ${ }^{[61]}$ 也分别开展了类似的实验研究. 但截至目 前, 基于横向电流测量的实验也未能实现单碱基分辨 率的DNA 检测.

\section{2 其他信号}

除离子电流和横向电流等电信号检测外, 还出现 了利用生物分子穿过纳米孔时的阻力差异来进行检测 的报道 ${ }^{[49,64,79 ~ 81]}$. 如图7(d) 所示, 本课题组 ${ }^{[78]}$ 发现, 用 AFM的针尖拖动单链DNA穿过石墨烯纳米孔时，由于 不同碱基通过纳米孔的阻力不同会导致所得力信号产 生差异. 具体来说, 当某个DNA碱基到达孔口时, 由于 尺寸等因素引起的阻力使其不能直接穿过, 随着拉力 的逐渐增大, 直到超过阻力以后, 碱基会迅速穿过纳米 孔. 因此, 力信号会存在一个非常明显的峰值, 根据峰 值大小即可判断碱基的类型 ${ }^{[64,81]}$. 但是, 与带电聚合物 在电场作用下自发穿过纳米孔不同，这种方式需要人 工引导检测物进入纳米孔并用AFM检测力信号. 进行 大规模测序时, 这类方法面临着相当大的挑战.

\section{5 总结和展望}

基于二维材料纳米孔的传感器件在DNA测序、 蛋白质分析等单分子检测领域展现了广阔的应用前 景. 一方面, 石墨烯等二维材料的极低厚度使其拥有潜
在的分辨单碱基的能力. 另一方面, 具有导电性二维材 料的采用为检测提供了膜内电流这一具有高带宽的测 量途径. 然而, 对包括二维材料在内的所有固态纳米孔 而言, 尽管研究人员开展了大量单分子检测的研究, 但 迄今为止, 仍然没有成功用于DNA测序的实验报道. 也就是说，在真正用于DNA测序等需要超高分辨率的 检测领域之前, 需要面对和解决很多挑战, 包括: 适合 用来测序的纳米孔尺寸的范围有多大? 采用离子电流 还是横向电流测量? 如何降低电流噪声? 如何在不给 信号带来更大噪声的前提下进一步大幅降低DNA过 孔速率等. 然而, 蛋白纳米孔在DNA测序方面取得的 成功暗示着二维材料等固态纳米孔也有望取得突破. 为了实现这一目标，下面提出未来一段时间内值得努 力的方向.

\section{1 选择合适的材料和结构}

一方面是二维材料种类和层数的合适选取. 在二 维材料纳米孔检测领域, 最先被提出且被研究最多的 仍然是石墨烯纳米孔. 逐渐被关注的其他二维材料纳 米孔也拥有各自的优势. 单层石墨烯纳米孔具有单原 子层厚度, 拥有理论上最高的分辨率但却存在更高的 噪声; 二硫化钼纳米孔具有更低的DNA黏附特性和较 小的噪声; 氮化硼纳米孔具有良好的形状重复性(三角 形), 在器件标准化方面独具潜力. 最近, 也有一些基于 二硫化铇 $\left(\mathrm{WS}_{2}\right)^{[82]}$ 和MXenes 族 ${ }^{[83]}$ 等二维材料上的纳米 孔进行检测的报道. 此外, 不同种类的二维材料堆叠形 成异质结会使膜的两侧具有不同的性质(亲疏水性), 为 二维材料纳米孔器件合成提供了更多膜的类型选择. 例如, 当石墨烯和二硫化锄形成异质结时, DNA会自发 从膜的一侧以单碱基逐个通过的方式从二硫化钼的一 侧运动到石墨烯一侧, 展现了异质结的运动控制能 力 $^{[45]}$. 此外, 选择合适的层数也是二维材料纳米孔必须 面对的问题. 尽管单层具有最高的理论分辨率, 但有研 究表明, 在噪声、DNA过孔速率方面, 少数层(如三层) 是比单层材料更好的选择 ${ }^{[31]}$. 最后一方面为二维材料 本身尺寸和边缘形状的精准控制. 针对膜内电流测量 这一检测途径而言, 所采用的石墨烯条带在边缘为扶 手椅型和锯齿形时具有截然不同的检测性质. 当将石 墨烯边缘裁剪成量子点接触结构时, 会比一般的石墨 烯条带(如扶手椅型)具有更高的检测灵敏度. 这些进展 表明, 采用横向电流测量时, 对二维材料尺寸和形状的 精准控制(特别是实验方面)是实现优异检测能力的 
前提.

\section{2 进一步控制生物分子的运动}

为了在单链DNA通过二维材料纳米孔时获得对应 于每个核苷酸的信号，DNA链上的核苷酸需要逐个通 过纳米孔. 为了降低噪声, 核苗酸在孔内应具有较低的 构型波动. 除了上述提及的方式以外, 研究人员基于氮 化硅等传统纳米孔体系提出的大量控制生物分子运动 的方法对二维材料纳米孔也应该是适用的. 常见的手 段包括降低跨膜电压或溶液温度，提高溶液黏性或改 变溶液离子种类和浓度等 ${ }^{[84 ~ 86]}$. 除了溶液环境的影响 外，对于固态纳米孔尺寸、表面状态和膜材料类型的 调控也能起到降低分子通过纳米孔速度的作用. 例如, Wanunu等人 ${ }^{[87]}$ 的实验研究发现，当孔变小时，较强的 DNA-纳米孔相互作用会明显增加DNA通过纳米孔的 时间. Venkatesan等人 ${ }^{[88]}$ 发现DNA通过氧化铝纳米孔明 显要慢于直径相当的氮化硅纳米孔，并认为这是由带 正电的氧化铝孔表面和带负电的DNA双链之间的强静 电相互作用引起的. 此外, 除了控制生物分子运动来抑 制噪声以外, 通过机器学习等新颖分析工具对电流数
据进行后处理，也有望提高纳米孔检测的灵敏度和分 辨率. 例如, 多个课题组通过人工神经网络等算法改进 了MinION等商用生物孔纳米孔测序设备的精度 ${ }^{[89,90]}$.

\section{3 开发新应用场景}

目前来看，离二维材料纳米孔用于DNA测序等需 要高分辨率的应用还有很长的路要走，因此现阶段可 以开发适合于二维材料纳米孔当前检测能力的应用. 领域内已经有一些这方面的报道. 例如, 有课题组提出 通过蛋白对DNA甲基化位点进行标记后，就能对甲基 化位点进行检测和准确定位 ${ }^{[40]}$. 此外, $\mathrm{Si}$ 等人 ${ }^{[91]}$ 用纳米 孔来区分单链DNA和G-四聚体，不限于DNA检测，更 大直径的纳米孔还可用于蛋白质分析和病毒检测

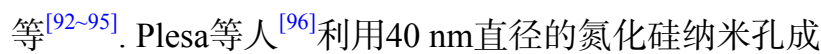
功分辨了 5 种蛋白质. 蛋白质和DNA的复合物(proteinDNA complexes)也是纳米孔检测范围 ${ }^{[51,97 ~ 100]}$. 除单分 子检测以外，同样基于纳米孔的海水淡化 ${ }^{[101,102]}$, 离子 逻辑电路 ${ }^{[103,104]}$ 、能量转化 ${ }^{[105,106]}$ 和分离 ${ }^{[107]}$ 等领域的 突破也有望为纳米孔检测技术的进一步优化带来新的 启发。

\section{参考文献}

1 Shi W, Friedman A K, Baker L A. Nanopore sensing. Anal Chem, 2017, 89: 157-188

2 Wanunu M. Nanopores: A journey towards DNA sequencing. Phys Life Rev, 2012, 9: 125-158

3 Kasianowicz J J, Brandin E, Branton D, et al. Characterization of individual polynucleotide molecules using a membrane channel. Proc Natl Acad Sci USA, 1996, 93: 13770-13773

4 Derrington I M, Butler T Z, Collins M D, et al. Nanopore DNA sequencing with MspA. Proc Natl Acad Sci USA, 2010, 107: 16060-16065

5 Manrao E A, Derrington I M, Laszlo A H, et al. Reading DNA at single-nucleotide resolution with a mutant MspA nanopore and phi29 DNA polymerase. Nat Biotechnol, 2012, 30: 349-353

6 Laszlo A H, Derrington I M, Brinkerhoff H, et al. Detection and mapping of 5-methylcytosine and 5-hydroxymethylcytosine with nanopore MspA. Proc Natl Acad Sci USA, 2013, 110: 18904-18909

7 Cao C, Ying Y L, Hu Z L, et al. Discrimination of oligonucleotides of different lengths with a wild-type aerolysin nanopore. Nat Nanotechnol, 2016, 11: 713-718

8 Ashton P M, Nair S, Dallman T, et al. MinION nanopore sequencing identifies the position and structure of a bacterial antibiotic resistance island. Nat Biotechnol, 2015, 33: 296-300

9 Jain M, Fiddes I T, Miga K H, et al. Improved data analysis for the MinION nanopore sequencer. Nat Methods, 2015, 12: 351-356

10 Venkatesan B M, Bashir R. Nanopore sensors for nucleic acid analysis. Nat Nanotechnol, 2011, 6: 615-624

11 Li J, Stein D, McMullan C, et al. Ion-beam sculpting at nanometre length scales. Nature, 2001, 412: 166-169

12 Garaj S, Hubbard W, Reina A, et al. Graphene as a subnanometre trans-electrode membrane. Nature, 2010, 467: 190-193

13 Merchant C A, Healy K, Wanunu M, et al. DNA translocation through graphene nanopores. Nano Lett, 2010, 10: 2915-2921

14 Schneider G F, Kowalczyk S W, Calado V E, et al. DNA translocation through graphene nanopores. Nano Lett, 2010, 10: 3163-3167

15 Liu K, Feng J, Kis A, et al. Atomically thin molybdenum disulfide nanopores with high sensitivity for DNA translocation. ACS Nano, 2014, 8 : 2504-2511

16 Farimani A B, Min K, Aluru N R. DNA base detection using a single-layer MoS $_{2}$. ACS Nano, 2014, 8: 7914-7922

17 Shim J, Banerjee S, Qiu H, et al. Detection of methylation on dsDNA using nanopores in a $\mathrm{MoS}_{2}$ membrane. Nanoscale, 2017, 9: 14836-14845 
18 Liu S, Lu B, Zhao Q, et al. Boron nitride nanopores: Highly sensitive DNA single-molecule detectors. Adv Mater, 2013, 25: 4549-4554

19 Liu K, Lihter M, Sarathy A, et al. Geometrical effect in 2D nanopores. Nano Lett, 2017, 17: 4223-4230

20 Aksimentiev A, Heng J B, Timp G, et al. Microscopic kinetics of DNA translocation through synthetic nanopores. Biophys J, 2004, 87: 20862097

21 Girdhar A, Sathe C, Schulten K, et al. Graphene quantum point contact transistor for DNA sensing. Proc Natl Acad Sci USA, 2013, 110: 1674816753

22 Carter J M, Hussain S. Robust long-read native DNA sequencing using the ONT CsgG nanopore system. Wellcome Open Res, 2017, 2: 23

23 Zhou W, Qiu H, Guo Y, et al. Molecular insights into distinct detection properties of $\alpha$-hemolysin, MspA, CsgG, and aerolysin nanopore sensors. J Phys Chem B, 2020, 124: 1611-1618

24 Heng J B, Aksimentiev A, Ho C, et al. Stretching DNA using the electric field in a synthetic nanopore. Nano Lett, 2005, 5: 1883-1888

25 Novoselov K S, Geim A K, Morozov S V, et al. Electric field effect in atomically thin carbon films. Science, 2004, 306: 666-669

26 Novoselov K S, Jiang D, Schedin F, et al. Two-dimensional atomic crystals. Proc Natl Acad Sci USA, 2005, 102: 10451-10453

27 Sathe C, Zou X, Leburton J P, et al. Computational investigation of DNA detection using graphene nanopores. ACS Nano, 2011, 5: 8842-8851

28 Aksimentiev A, Schulten K. Imaging $\alpha$-hemolysin with molecular dynamics: Ionic conductance, osmotic permeability, and the electrostatic potential map. Biophys J, 2005, 88: 3745-3761

29 Bhattacharya S, Yoo J, Aksimentiev A. Water mediates recognition of DNA sequence via ionic current blockade in a biological nanopore. ACS Nano, 2016, 10: 4644-4651

30 Liang L, Cui P, Wang Q, et al. Theoretical study on key factors in DNA sequencing with graphene nanopores. RSC Adv, 2013, 3: 2445-2453

31 Wells D B, Belkin M, Comer J, et al. Assessing graphene nanopores for sequencing DNA. Nano Lett, 2012, 12: 4117-4123

$32 \mathrm{Lv}$ W, Liu S, Li X, et al. Spatial blockage of ionic current for electrophoretic translocation of DNA through a graphene nanopore. Electrophoresis, 2014, 35: 1144-1151

33 Li J, Zhang Y, Yang J, et al. Molecular dynamics study of DNA translocation through graphene nanopores. Phys Rev E, 2013, 87: 062707

34 Yu Y S, Lu X, Ding H M, et al. Computational investigation on DNA sequencing using functionalized graphene nanopores. Phys Chem Chem Phys, 2018, 20: 9063-9069

35 Shi C, Kong Z, Sun T, et al. Molecular dynamics simulations indicate that DNA bases using graphene nanopores can be identified by their translocation times. RSC Adv, 2015, 5: 9389-9395

$36 \mathrm{Lv} \mathrm{W}$, Chen M, Wu R. The impact of the number of layers of a graphene nanopore on DNA translocation. Soft Matter, 2013, 9: 960-966

37 Liang L, Zhang Z, Shen J, et al. Theoretical studies on the dynamics of DNA fragment translocation through multilayer graphene nanopores. RSC Adv, 2014, 4: 50494-50502

38 Li J, Wang H, Li Y, et al. The impact of the number of layers of the graphene nanopores and the electrical field on ssDNA translocation. Mol Simul, 2017, 43: 320-325

39 Wilson J, Aksimentiev A. Water-compression gating of nanopore transport. Phys Rev Lett, 2018, 120: 268101

40 Qiu H, Sarathy A, Schulten K, et al. Detection and mapping of DNA methylation with 2D material nanopores. npj 2D Mater Appl, 2017, 1: 3

41 Watanabe K, Taniguchi T, Kanda H. Direct-bandgap properties and evidence for ultraviolet lasing of hexagonal boron nitride single crystal. Nat Mater, 2004, 3: 404-409

42 Gu Z, Zhang Y, Luan B, et al. DNA translocation through single-layer boron nitride nanopores. Soft Matter, 2016, 12: 817-823

43 He Z, Zhou R. Planar graphene/h-BN/graphene heterostructures for protein stretching and confinement. Nanoscale, 2020, 12: 13822-13828

44 Luan B, Zhou R. Spontaneous ssDNA stretching on graphene and hexagonal boron nitride in plane heterostructures. Nat Commun, 2019 , 10: 4610

45 Luan B, Zhou R. Spontaneous transport of single-stranded DNA through graphene-MoS $\mathrm{M}_{2}$ heterostructure nanopores. ACS Nano, 2018, 12: 38863891

46 Shankla M, Aksimentiev A. Conformational transitions and stop-and-go nanopore transport of single-stranded DNA on charged graphene. Nat Commun, 2014, 5: 5171

47 Shankla M, Aksimentiev A. Step-defect guided delivery of DNA to a graphene nanopore. Nat Nanotechnol, 2019, 14: 858-865

$48 \mathrm{Si} \mathrm{W}$, Zhang Y, Sha J, et al. Controllable and reversible DNA translocation through a single-layer molybdenum disulfide nanopore. Nanoscale, 2018, 10: 19450-19458

49 Qiu H, Sarathy A, Leburton J P, et al. Intrinsic stepwise translocation of stretched ssDNA in graphene nanopores. Nano Lett, 2015, 15: 8322-8330

50 Qiu H, Girdhar A, Schulten K, et al. Electrically tunable quenching of DNA fluctuations in biased solid-state nanopores. ACS Nano, 2016, 10: $4482-4488$

51 Venkatesan B M, Estrada D, Banerjee S, et al. Stacked graphene- $\mathrm{Al}_{2} \mathrm{O}_{3}$ nanopore sensors for sensitive detection of DNA and DNA-protein complexes. ACS Nano, 2012, 6: 441-450

52 Banerjee S, Wilson J, Shim J, et al. Slowing DNA transport using graphene-DNA interactions. Adv Funct Mater, 2015, 25: 936-946 
53 Kumar A, Park K B, Kim H M, et al. Noise and its reduction in graphene based nanopore devices. Nanotechnology, 2013, 24: 495503

54 Heerema S J, Schneider G F, Rozemuller M, et al. 1/f noise in graphene nanopores. Nanotechnology, 2015, 26: 074001

55 Garaj S, Liu S, Golovchenko J A, et al. Molecule-hugging graphene nanopores. Proc Natl Acad Sci USA, 2013, 110: 12192-12196

56 Fujita M, Wakabayashi K, Nakada K, et al. Peculiar localized state at zigzag graphite edge. J Phys Soc Jpn, 1996, 65: 1920-1923

57 Sasaki K, Murakami S, Saito R. Gauge field for edge state in graphene. J Phys Soc Jpn, 2006, 75: 074713

58 Nakada K, Fujita M, Dresselhaus G, et al. Edge state in graphene ribbons: Nanometer size effect and edge shape dependence. Phys Rev B, 1996, 54: 17954-17961

59 Brey L, Fertig H A. Electronic states of graphene nanoribbons studied with the Dirac equation. Phys Rev B, 2006, 73: 235411

60 Nelson T, Zhang B, Prezhdo O V. Detection of nucleic acids with graphene nanopores: Ab initio characterization of a novel sequencing device. Nano Lett, 2010, 10: 3237-3242

61 Heerema S J, Vicarelli L, Pud S, et al. Probing DNA translocations with inplane current signals in a graphene nanoribbon with a nanopore. ACS Nano, 2018, 12: 2623-2633

62 Traversi F, Raillon C, Benameur S M, et al. Detecting the translocation of DNA through a nanopore using graphene nanoribbons. Nat Nanotechnol, 2013, 8: 939-945

63 Saha K K, Drndić M, Nikolić B K. DNA base-specific modulation of microampere transverse edge currents through a metallic graphene nanoribbon with a nanopore. Nano Lett, 2012, 12: 50-55

64 Qiu H, Guo W. Detecting ssDNA at single-nucleotide resolution by sub-2-nanometer pore in monoatomic graphene: A molecular dynamics study. Appl Phys Lett, 2012, 100: 083106

65 Bayley H. Holes with an edge. Nature, 2010, 467: 164-165

66 Prasongkit J, Grigoriev A, Pathak B, et al. Transverse conductance of DNA nucleotides in a graphene nanogap from first principles. Nano Lett, 2011, 11: 1941-1945

67 Zhao Q, Wang Y, Dong J, et al. Nanopore-based DNA analysis via graphene electrodes. J Nanomater, 2012, 2012: 1-5

$68 \mathrm{He}$ Y, Scheicher R H, Grigoriev A, et al. Enhanced DNA sequencing performance through edge-hydrogenation of graphene electrodes. Adv Funct Mater, 2011, 21: 2674-2679

69 Ouyang F P, Peng S L, Zhang H, et al. A biosensor based on graphene nanoribbon with nanopores: A first-principles devices-design. Chin Phys B, 2011, 20: 058504

70 de Souza F A L, Amorim R G, Scopel W L, et al. Electrical detection of nucleotides via nanopores in a hybrid graphene/h-BN sheet. Nanoscale, 2017, 9: 2207-2212

71 Sadeghi H, Algaragholy L, Pope T, et al. Graphene sculpturene nanopores for DNA nucleobase sensing. J Phys Chem B, 2014, 118: 6908-6914

72 Ahmed T, Haraldsen J T, Rehr J J, et al. Correlation dynamics and enhanced signals for the identification of serial biomolecules and DNA bases Nanotechnology, 2014, 25: 125705

73 Ahmed T, Haraldsen J T, Zhu J X, et al. Next-generation epigenetic detection technique: Identifying methylated cytosine using graphene nanopore. J Phys Chem Lett, 2014, 5: 2601-2607

74 Avdoshenko S M, Nozaki D, Gomes da Rocha C, et al. Dynamic and electronic transport properties of DNA translocation through graphene nanopores. Nano Lett, 2013, 13: 1969-1976

75 Sathe C, Girdhar A, Leburton J P, et al. Electronic detection of dsDNA transition from helical to zipper conformation using graphene nanopores Nanotechnology, 2014, 25: 445105

76 Girdhar A, Sathe C, Schulten K, et al. Tunable graphene quantum point contact transistor for DNA detection and characterization Nanotechnology, 2015, 26: 134005

77 Sarathy A, Qiu H, Leburton J P. Graphene nanopores for electronic recognition of DNA methylation. J Phys Chem B, 2017, 121: 3757-3763

78 Puster M, Balan A, Rodríguez-Manzo J A, et al. Cross-talk between ionic and nanoribbon current signals in graphene nanoribbon-nanopore sensors for single-molecule detection. Small, 2015, 11: 6309-6316

79 Zhang Z, Shen J, Wang H, et al. Effects of graphene nanopore geometry on DNA sequencing. J Phys Chem Lett, 2014, 5: 1602-1607

80 Li K, Si W, Sha J, et al. Molecular dynamics study of DNA translocation through graphene nanopores with controllable speed. In: ASME 2015 International Mechanical Engineering Congress and Exposition. New York: ASME Press, 2015. 7B

81 Si W, Zhang Y, Wu G, et al. Discrimination of protein amino acid or its protonated state at single-residue resolution by graphene nanopores. Small, 2019, 15: 1900036

82 Danda G, Masih Das P, Chou Y C, et al. Monolayer $\mathrm{WS}_{2}$ nanopores for DNA translocation with light-adjustable sizes. ACS Nano, 2017, 11: $1937-1945$

83 Mojtabavi M, VahidMohammadi A, Liang W, et al. Single-molecule sensing using nanopores in two-dimensional transition metal carbide (MXene) membranes. ACS Nano, 2019, 13: 3042-3053 
84 Fologea D, Uplinger J, Thomas B, et al. Slowing DNA translocation in a solid-state nanopore. Nano Lett, 2005, 5: 1734-1737

85 Kowalczyk S W, Wells D B, Aksimentiev A, et al. Slowing down DNA translocation through a nanopore in lithium chloride. Nano Lett, 2012, 12: 1038-1044

86 Luan B, Stolovitzky G, Martyna G. Slowing and controlling the translocation of DNA in a solid-state nanopore. Nanoscale, 2012, 4: 1068-1077

87 Wanunu M, Sutin J, McNally B, et al. DNA translocation governed by interactions with solid-state nanopores. Biophys J, 2008, 95: 4716-4725

88 Venkatesan B M, Shah A B, Zuo J M, et al. DNA sensing using nanocrystalline surface-enhanced $\mathrm{Al}_{2} \mathrm{O}_{3}$ nanopore sensors. Adv Funct Mater, 2010, 20: 1266-1275

89 Teng H, Cao M D, Hall M B, et al. Chiron: Translating nanopore raw signal directly into nucleotide sequence using deep learning. GigaScience, 2018, 7: 1-9

90 Liu Q, Fang L, Yu G, et al. Detection of DNA base modifications by deep recurrent neural network on Oxford Nanopore sequencing data. Nat Commun, 2019, 10: 2449

91 Si W, Yang H, Sha J, et al. Discrimination of single-stranded DNA homopolymers by sieving out G-quadruplex using tiny solid-state nanopores. Electrophoresis, 2019, 40: 2117-2124

92 Larkin J, Henley R Y, Muthukumar M, et al. High-bandwidth protein analysis using solid-state nanopores. Biophys J, 2014, 106: 696-704

93 Li W, Bell N A W, Hernández-Ainsa S, et al. Single protein molecule detection by glass nanopores. ACS Nano, 2013, 7: 4129-4134

94 Wei R, Gatterdam V, Wieneke R, et al. Stochastic sensing of proteins with receptor-modified solid-state nanopores. Nat Nanotechnol, 2012, 7: $257-263$

95 Han A, Schürmann G, Mondin G, et al. Sensing protein molecules using nanofabricated pores. Appl Phys Lett, 2006, 88: 093901

96 Plesa C, Kowalczyk S W, Zinsmeester R, et al. Fast translocation of proteins through solid state nanopores. Nano Lett, 2013, 13: 658-663

97 Kowalczyk S W, Hall A R, Dekker C. Detection of local protein structures along DNA using solid-state nanopores. Nano Lett, 2010, 10: 324-328

98 Hall A R, van Dorp S, Lemay S G, et al. Electrophoretic force on a protein-coated DNA molecule in a solid-state nanopore. Nano Lett, 2009, 9: $4441-4445$

99 Marshall M M, Ruzicka J, Zahid O K, et al. Nanopore analysis of single-stranded binding protein interactions with DNA. Langmuir, 2015, 31: 4582-4588

100 Plesa C, Ruitenberg J W, Witteveen M J, et al. Detection of individual proteins bound along DNA using solid-state nanopores. Nano Lett, 2015, 15: $3153-3158$

101 Li W, Yang Y, Weber J K, et al. Tunable, strain-controlled nanoporous $\mathrm{MoS}_{2}$ filter for water desalination. ACS Nano, 2016, 10: 1829-1835

102 Cohen-Tanugi D, Grossman J C. Water desalination across nanoporous graphene. Nano Lett, 2012, 12: 3602-3608

103 Jiang Y, Liu N, Guo W, et al. Highly-efficient gating of solid-state nanochannels by DNA supersandwich structure containing ATP aptamers: A nanofluidic IMPLICATION logic device. J Am Chem Soc, 2012, 134: 15395-15401

104 Nam S W, Rooks M J, Kim K B, et al. Ionic field effect transistors with sub-10 nm multiple nanopores. Nano Lett, 2009, 9: 2044-2048

105 Feng J, Graf M, Liu K, et al. Single-layer $\mathrm{MoS}_{2}$ nanopores as nanopower generators. Nature, 2016, 536: 197-200

106 Ramirez P, Gomez V, Cervera J, et al. Energy conversion from external fluctuating signals based on asymmetric nanopores. Nano Energy, 2015, 16: $375-382$

107 Li D, Hu W, Zhang J, et al. Separation of hydrogen gas from coal gas by graphene nanopores. J Phys Chem C, 2015, 119: 25559-25565 


\title{
Two-dimensional material nanopores as biosensors: Recent progress based on computations and simulations
}

\author{
Wanqi Zhou ${ }^{1,2}$, Hu Qiu ${ }^{1,2 *}$, Yufeng Guo ${ }^{1,2} \&$ Wanlin Guo ${ }^{1,2}$ \\ ${ }^{1}$ State Key Laboratory of Mechanics and Control of Mechanical Structures, Nanjing University of Aeronautics and Astronautics, Nanjing 210016, Chi- \\ na; \\ ${ }^{2}$ Key Laboratory for Intelligent Nano Materials and Devices of Ministry of Education, Nanjing University of Aeronautics and Astronautics, Nanjing \\ 210016, China \\ * Corresponding author, E-mail: qiuhu@nuaa.edu.cn
}

The passage of molecules through nanoscale pores is ubiquitous in biology. Inspired by this process, nanopore-based biosensors were proposed and have been widely used to probe, analyze or manipulate single biomolecules, such as DNA, RNA and protein. In a typical nanopore experiment, a thin membrane containing a nanoscale pore is used to separate two chambers of conducting electrolyte solution. As a transmembrane voltage bias is applied, analytes (such as DNA and RNA) in solution are driven through the nanopore, leading to changes in recorded ionic current traces. These changes are related to physical or chemical properties of the translocating molecules (analytes) such as structure, configuration and even identity. When DNA molecules are used as the analytes, the ionic current signal could be used to recognize individual bases, and in turn, the DNA sequence. The advantage of nanopore method for sequencing applications lies in its low cost, high efficiency, and ultra-long reads, because it eliminates the need for sample amplification and fluorescence labeling steps.

In 1996, Kasianowicz et al. reported the first experiment of single-stranded DNA and RNA molecules passing through the biological pore $\alpha$-hemolysin. In the following years, many other biological nanopores were used in order to obtain sufficient current and temporal resolution for single-molecule analysis. For example, the MspA nanopore, incorporated with Phi29 DNA polymerase, is able to read the sequence information of a single-stranded DNA (ssDNA) through measured ionic current. The relatively sharp and short constriction of the MspA nanopore compared to other biological nanopores (e.g., $\alpha$-hemolysin) is regarded as the structural origin for its outstanding sensing ability. In particular, the length of the constriction in the MspA nanopore is equivalent to the distance between neighboring DNA bases in an ssDNA strand. This observation implied that a monolayer of typical two-dimensional (2D) materials such as graphene, with a thickness also equivalent to the spatial interval of DNA bases, is a promising candidate for DNA sequencing. On one hand, 2D material nanopores share inherent advantages of traditional solid-state nanopores, such as high stability over a broad range of temperature, $\mathrm{pH}$ and applied electric fields. On the other hand, the extreme thinness of $2 \mathrm{D}$ material nanopores is expected to deliver much higher spatial resolution than nanopores in traditional solid-state membranes such as silicon nitride and silicon oxide, which typically contain hundreds of bases in the pores simultaneously. Furthermore, the use of electrically conducting 2D materials offers the possibility to detect analytes at higher bandwidths, namely, by measuring transverse in-plane current through 2D material nanoribbons.

During the development of nanopores sensors, computational tools such as first principle calculations and molecular dynamics simulations that can resolve molecular-scale interactions in nanopores have made significant contributions to this area in terms of prediction of novel detection approaches, optimization of device performance and explanation of experimental phenomena, etc. Here, with a standing point of computations and simulations, this review surveys the milestones in the area of 2D material nanopore-based biosensors, and the key experimental progress is also briefly discussed. Not limited to ionic current measurement, several other measurement methods such as transverse current in a nanoribbon and force traces during the pulling of biomolecules through nanopores are also introduced. This review further outlines key factors that restrict the performance of these sensors and discusses challenges and possible solutions. The key challenges include fast biomolecular translocation across nanopores and high noise levels in the recorded signal, etc. Finally, we provide a discussion on the future direction for the field, including the rational choice of 2D material, precise control over molecular movement inside nanopores as well as exploration of new applications.

nanopore sensors, DNA sequencing, 2D material, graphene, computer simulations

doi: $10.1360 / \mathrm{TB}-2020-1051$ 